OPEN ACCESS

Edited by:

Gilad Antler,

Ben-Gurion University of the Negev,

Israel

Reviewed by:

Ashley Brooke Cohen,

Montana State University,

United States

Christian Schröder,

University of Stirling, United Kingdom

*Correspondence: Brandy M. Toner toner@umn.edu

Specialty section: This article was submitted to

Biogeoscience,

a section of the journal

Frontiers in Earth Science

Received: 27 October 2021 Accepted: 17 January 2022

Published: 02 March 2022

Citation:

Schuler CJ, Briscoe LJ, Alexander SC, Alexander EC, Gralnick JA, Santelli CM and Toner BM (2022) Water and Rock Chemistry Inform Our Understanding of the Deep Biosphere: Case Study in an Archaean Banded Iron Formation.

Front. Earth Sci. 10:803250.

doi: 10.3389/feart.2022.803250

\section{Water and Rock Chemistry Inform Our Understanding of the Deep Biosphere: Case Study in an Archaean Banded Iron Formation}

\author{
Cristopher J. Schuler ${ }^{1}$, Lindsey J. Briscoe ${ }^{1}$, Scott C. Alexander ${ }^{1}$, E. Calvin Alexander Jr ${ }^{1}$, \\ Jeffrey A. Gralnick ${ }^{2,3}$, Cara M. Santelli ${ }^{1,2}$ and Brandy M. Toner ${ }^{1,4 *}$ \\ ${ }^{1}$ Department of Earth and Environmental Sciences, University of Minnesota-Twin Cities, Minneapolis, MN, United States, \\ ${ }^{2}$ BioTechnology Institute, University of Minnesota - Twin Cities, St. Paul, MN, United States, ${ }^{3}$ Department of Plant and Microbial \\ Biology, University of Minnesota - Twin Cities, St. Paul, MN, United States, ${ }^{4}$ Department of Soil, Water, and Climate, University of \\ Minnesota-Twin Cities, St. Paul, MN, United States
}

Research into the deep biosphere requires an understanding of both the microbial community at a given site and the geochemical and hydrological factors that support that microbial community. To highlight the interplay between geochemistry and microbiology in these deep environments, we characterized the hydrogeologic and geochemical systems of a $2.7 \mathrm{Ga}$ banded iron formation within the Canadian Shield in the Soudan Underground Mine State Park in Minnesota, United States, a site known to host a lithotrophic microbial community. Calcium-sodium-chloride brines, characteristic of deep groundwaters throughout the Canadian Shield, were found in the site with total dissolved constituents (<0.2 micron) as high as 116,000 mg/L (ppm) in one borehole. Comparison of the Soudan waters to those found at other sites in the Canadian Shield or other sites of deep biosphere research indicate that they are notable for their high magnesium concentrations relative to total salinity. Additionally, the most saline Soudan waters have distinct ${ }^{2} \mathrm{H}$ and ${ }^{18} \mathrm{O}$ water isotope values suggesting long periods of isolation from the surface, which would allow for the evolution of a distinctive subsurface community. The presence of the banded iron formation along with the long-term isolation of the shield waters make Soudan a site of great potential for future research into deep crustal life. Furthermore, our work at Soudan highlights how geochemical data can inform future research into the deep biosphere and highlights a path for future research at the mine.

Keywords: deep biosphere, Canadian shield, brine, aquifer, banded iron formation, continental subsurface

\section{INTRODUCTION}

The deep crustal rocks of the Canadian Shield contain uniquely old and isolated groundwaters. As such, they are an ideal location to interrogate the deep continental biosphere and the biogeochemical processes supporting life in this harsh environment. The Shield spans from the Northwest Territories to Newfoundland in Canada and extends as far south as Minnesota and New York. It hosts the oldest crustal rocks in North America, with some rocks dating to over $4.2 \mathrm{Ga}$ (O’Neil \& Carlson, 2017). In deep shield environments where water has been sampled, salinities several times greater than 
seawater are commonly found (Frape et al., 1984). These waters are isolated from the surface, i.e., contain no influx of meteoric waters, on all but the longest time scales-noble gas isotopes indicate that the most isolated of these waters have a subsurface residence time above $1 \mathrm{Ga}$ (Holland et al., 2013). The scientific community has known of the existence of microbial communities in the deep fracture systems of the Canadian Shield for over three decades (Sherwood Lollar et al., 1993). However, few studies have been conducted on subsurface life in the Canadian Shield, perhaps in part due to the inaccessibility of the groundwaters (Edwards et al., 2006; Onstott et al., 2009; Telling et al., 2018).

Far more attention has been paid to deep subsurface microbial communities in other regions with similarly old continental crust. The Fennoscandian Shield contains brines similar to those in the Canadian Shield. One site in this region, the Outokumpu Deep Drill Hole, has reached waters with residence times between 20-50 Ma (Kietäväinen et al., 2014). Deep biosphere research in the Fennoscandian Shield has spanned three decades and incorporated a wide variety of microbial techniques, including culturing, targeted amplicon sequencing, and several meta-omic methods (Szewzyk et al., 1994; Pedersen et al., 1996; Bell et al., 2018; Lopez-Fernandez et al., 2018b). Likewise, boreholes in the Mponeng Gold Mine, located in the Kaapvaal Craton of southern Africa, access waters with residence times between 15-25 Ma (Lin et al., 2006). Investigations into microbial interactions with the geosphere in the Kaapvaal Craton started later than Fennoscandian Shield studies, but have nonetheless been ongoing for 2 decades (Baker et al., 2003; Moser et al., 2003; Simkus et al., 2016; Magnabosco et al., 2018). These deep crustal hydrogeologic systems are often hundreds of meters below sea level with little hydraulic gradient to drive recent meteoric circulation, and thus have the potential to host the longestisolated groundwaters. For this reason, they can likewise host the longest-isolated subsurface microbial communities. The degree of isolation of a given hydrogeologic system, then, is one proxy for how distinct its microbial community may be from those on the surface. Comprehensive geological and microbial community studies of these sites are important because they may host novel microbial communities. Furthermore, they can be used as natural labs to gain insight into potential extraterrestrial microbial communities (Jones et al., 2018).

Because of the separation from the Earth's surface, these microbial communities cannot depend on photosynthesis or photosynthetically derived carbon in the same manner as surface microbes. Recharge waters have likely been stripped of organic carbon before they reach the deep subsurface and its associated microbial communities (Lovley and Chapelle, 1995). Consequently, these microbial communities are thought to be supported by lithotrophic primary producers gaining energy through the oxidation and reduction of compounds in the water and surrounding rock (Stevens and Mckinley, 1995). The movement of water through fractures in the subsurface may also play an essential role, bringing in new substrates and removing waste products. A thorough characterization of these sites' waters is a necessary part of a comprehensive understanding of the deep biosphere. This strategy has been proven successful at sites such as the Äspö Hard Rock Laboratory, the Outukumpo Deep Drill Hole, the Deep Mine Microbial Observatory (DeMMO), and at Kidd Creek Mine (Pedersen, 1997; Ahonen et al., 2011; Itävaara et al., 2011; Lollar et al., 2019; Osburn et al., 2019). Interdisciplinary research is necessary to uncover feedbacks between microbes and their environments and provide more insight into the structure of life in the subsurface.

This paper provides a geochemical overview of the Soudan Underground Mine, a site in the southernmost portion of the Canadian Shield which accesses a $2.7 \mathrm{Ga}$ Archaean banded iron formation (BIF) within an Archaean Greenstone belt. These rocks contain waters which are known to host a unique and robust microbial community and which are geochemically similar to other continental shield brines (Edwards et al., 2006; Badalamenti et al., 2016; Sheik et al., 2021). The lithologies of the mine environment are well described through studies of archived cores and driller's logs from boreholes on the mine's lowest level, located $714 \mathrm{~m}$ below the surface; the chemistry of the water flowing from these boreholes was sampled over a 9 year period and reported here. Temporal and spatial trends in the geochemistry of the mine are identified for the purpose of guiding future microbial ecology investigations and interpreting the co-existence and co-evolution of the biosphere and geosphere of this deep terrestrial environment. These waters are then evaluated in the regional context of the Canadian Shield and in the context of the cratonic deep biosphere, demonstrating that water and rock chemistry can be used to identify ecological niches even in geologically similar sites.

\section{GEOLOGIC SETTING}

The Soudan Underground Mine State Park is located at the site of a historic iron mine in northern Minnesota at the base of the Canadian Shield. Active between 1882 and 1962, this mine produced the rich iron ore characteristic of the Vermillion Range. The mine itself accesses three rock formations with overlapping but distinct compositions. The Soudan Formation was the main target of the mine. It primarily contains a banded iron formation consisting of alternating hematite and chert layers. It also contains regions of high-purity hematite ore, which contain some quartz and sulfide impurities but no chert or jasper banding, as well as other sedimentary and metasedimentary rocks. It is bracketed on either side by the Upper and Lower Ely Greenstone Formations, both characteristic of the metabasalt formations found across the Canadian Shield. The Ely Greenstone formations are largely made up of metamorphosed lava flows, with the upper formation containing tholeiitic basalts interspersed with minor iron formation inclusions and the lower formation containing both basalts and calc-alkalic lava flows (Peterson and Patelke, 2003). The iron formation itself is thought to have formed initially through seafloor deposition, with deposition estimated to have begun at $3.0 \mathrm{Ga}$. After deposition, it evolved though extensive seafloor hydrothermal alteration. Two periods of deformation and alteration, occurring between 2.5 and $2.7 \mathrm{Ga}$, then formed the massive hematite ore body contained within it today (Cloud $\mathrm{Jr}$ et al., 1965; Peterson and Patelke, 2003; Thompson, 2015). 
Mining progressed to deeper levels until operations ceased in 1962 at the 27 th level, more than $700 \mathrm{~m}$ below the surface. Deeper areas, below the 27 th level, had been investigated via boreholes, all drilled while the mine was still active. The lowest level consists of two horizontal drifts, which access different geologic formations. The East drift accesses the Soudan Formation and the surrounding Upper Ely Greenstone; The West Drift accesses the Soudan Formation. Boreholes originating from the West Drift access more concentrated regions of banded iron formation and hematite ore. The boreholes of interest in this paper were drilled between 1958 and 1962; photographs of the boreholes can be seen in the supplemental information (Supplementary Figure S1). Though iron mining ceased in 1962, the mine was neither closed nor abandoned. The mining company gave the mine and all of its physical structures to the Minnesota Department of Natural Resources, which has continued to operate the mine as the Soudan Underground Mine State Park. The State Park has maintained the elevator to the 27th level and continues to pump water from the mine. Due to the ongoing pumping of the sump in the 27 th level, the mine has not filled with water. The pumping removes both seepage from the deep fracture networks and surface recharge through the abandoned higher levels of the mine.

\section{METHODS}

\section{Borehole Geology}

To determine the lithologies accessed by each borehole, several methods were used. Whenever possible, physical inspection of archived rock cores was used as a primary source for borehole lithologies. Archived core was available from the downwardangled boreholes on the West Drift: DDHs 932, 942, 944, and 951. However, these historic cores were skeletonized by the mining company, preserving only sparse examples of non-ore rocks. Representative images of the core can be found in the supplemental information (Supplementary Figure S2). Archived core inspection was augmented or replaced by referencing primary sources from the drilling of these boreholes, i.e., Driller's records from the time of drilling that include core lithology on a foot-by-foot basis and were used to augment or in place of physical inspections (Klinger, 1958; Bakkila, 1960a; Bakkila, 1960b; Bakkila, 1960c). Finally, these sources were supplemented with information from Minnesota Department of Natural Resources drill core reports and by geologic maps of the Soudan Mine and surrounding area (Dahlberg et al., 1989; Peterson and Patelke, 2003; Peterson, 2007; Peterson, 2019).

\section{Water Chemistry \\ Field Methods}

Field measurements of borehole water were performed with a Thermo Orion A329 multiparameter-meter. Temperature and conductance were measured using probe $013005 \mathrm{D}, \mathrm{pH}$ was measured using probe 9016BNWP, oxidation-reduction potential was measured using probe $9678 \mathrm{BN}$, and dissolved oxygen concentrations were measured using the optical probe
083005MD. For laboratory-based analyses, water samples were collected in sterile syringes and filtered through $0.2 \mu \mathrm{m}$ PES membranes into plastic sample tubes. Samples designated for cation analysis were preserved with one drop of $6 \mathrm{~N}$ ACS grade $\mathrm{HCl}$ per $15 \mathrm{ml}$, while samples designated for trace metal analysis were preserved with five drops of trace-metal grade $\mathrm{HNO}_{3}$ per $15 \mathrm{ml}$. No preservative was used for samples designated for anion analysis; however, these samples were re-filtered through $0.2 \mu \mathrm{m}$ polyethersulfone membranes (Millipore) immediately prior to analysis to remove any precipitated minerals (e.g., iron oxyhydroxides). Water samples were immediately stored on ice while in the field and were transferred to $5^{\circ} \mathrm{C}$ storage until analysis.

\section{Anions}

Anions were measured on Dionex ICS 2000 using a 4 mm AS19 column, a $4 \mathrm{~mm}$ ASRS 300 suppressor, a $\mathrm{NaOH}$ eluent generator, and a conductivity detector in the Analytical Geochemistry laboratory at the University of Minnesota. High salinity samples were diluted up to 100 -fold to keep measurements on scale based on field conductivity. The anions measured using this method were acetate, formate, oxalate, nitrite, nitrate, fluoride, phosphate, sulfate, thiosulfate, chloride, and bromide.

\section{Cations}

Major cations were measured on a Thermo Scientific iCAP 6500 ICP-OES using a Mira Mist PEEK nebulizer in the Analytical Geochemistry laboratory at the University of Minnesota. High salinity samples were diluted as with the anions. Samples were injected at the rate of $1 \mathrm{ml} / \mathrm{min}$ and $8 \mathrm{~s} /$ replicate with 5 replicates/sample. A yttrium standard was used to monitor internal consistency. The cations measured using this method were lithium, sodium, magnesium, aluminum, silicon, phosphorus, potassium, calcium, manganese, iron, strontium, and barium.

\section{Trace Elements}

Trace elements were measured in the Analytical Geochemistry laboratory at the University of Minnesota on a Thermo Scientific XSERIES 2 ICP-MS using an ESI PC3 Peltier-cooled spray chamber, an SC-FAST injection loop, and a SC-4 autosampler. Analytes were measured using the $\mathrm{He} / \mathrm{H}_{2}$ collision reaction mode. During sample dilution, $20 \mathrm{ppb}$ of an indium standard was added to monitor internal consistency. The elements measured using this method were lithium, aluminum, phosphorous, vanadium, chromium, manganese, iron, cobalt, nickel, copper, zinc, arsenic, selenium, rubidium, strontium, molybdenum, cadmium, tin, antimony, cesium, barium, hafnium, tellurium, lead, thorium, and uranium.

\section{Alkalinity}

Alkalinity was measured through the colorimetric titration of waters with Bromocresol green indicator. Alkalinity values are reported as an equivalent weight of carbonate.

\section{Isotopes}

\section{Deuterium and Stable Oxygen}

Water samples were collected in $30 \mathrm{ml}$ HDPE bottles which were first rinsed three times with the sample. Analyses were performed 


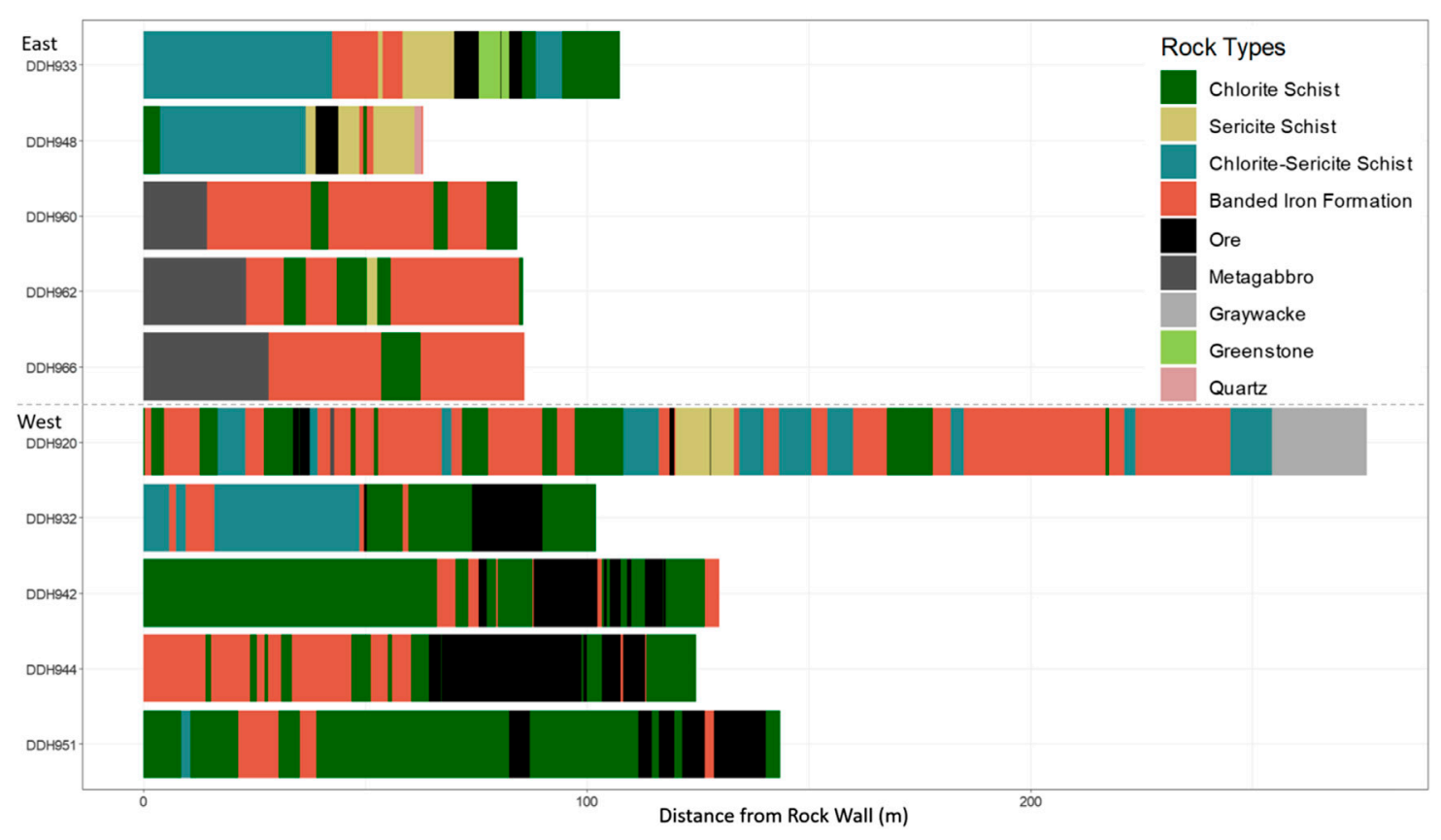

FIGURE 1 | Lithologies accessed by the boreholes of interest in this study, compiled from driller's logs and geologic maps of the Soudan Underground Mine's 27th level. DDH 964 was not included, as records of the lithologies it accessed could not be found.

at the Schwartz Isotope Laboratory at Texas State University in San Marcos, TX. Due to the high salinity of the borehole waters, samples were distilled prior to analysis. Isotopic ratios were measured on a Los Gatos Research model 908-0008 Liquid Water Stable Isotope Analyzer with Off-Axis Integrated Cavity Output Spectroscopy laser technology. Samples were analyzed eight times, with the first three analyses discarded to eliminate carry-over from the previous sample. To correct for instrumental drift, internal standards were run at the beginning and end of each run as well as after every third sample. Post-processing of raw data was run in a LIMS system by Tyler Coplen of USGS, Reston and reported relative to Vienna Standard Mean Ocean Water (VSMOW) $\left({ }^{2} \mathrm{H} /{ }^{1} \mathrm{H}=155.76 \pm 0.1 \mathrm{ppm} ;{ }^{18} \mathrm{O} /{ }^{16} \mathrm{O}=\right.$ $2005.20 \pm 0.43 \mathrm{ppm})$.

\section{Tritium}

Water samples were collected in 1 L HDPE bottles that had been washed and triple-rinsed with deionized water and dried overnight in an oven at $80^{\circ} \mathrm{C}$. Analysis was performed by Isotope Tracer Technologies, Inc. in Waterloo, OT, Canada. Samples were enriched through electrolysis and measured using a liquid scintillation counter.

\section{RESULTS}

\section{Geology Accessed by Boreholes of Interest}

The boreholes-of-interest within the Soudan Mine can be split into two sections: those drilled within the East Drift of the mine and those drilled within the West Drift. The two regions access distinct lithologies. Hematite ore and banded iron formation are more prevalent in the heavily sheared and deformed West Drift, while the East drift contains a wider variety of lithologies, including the Ely Greenstone, a formation composed of metamorphosed tholeiitic and calc-alkalic lava flows. As such, the lithologies accessed by each drift will be discussed separately. The lithologies accessed by each borehole can be seen in Figure 1. The physical characteristics of each borehole are given in Table $\mathbf{1}$. We note that these boreholes were not all drilled in the same direction but at different angles relative to the mine floor.

Though the lithologies assigned in Figure $\mathbf{1}$ are not perfectly uniform from point to point, they can be broadly described. A few rock types are made up of a single mineral phase, i.e., quartz and the hematite ore. The schistose lithologies are composed of simple silicate oxides mixed with more complex silicates-a chlorite, in the case of chlorite schist, a sericite, in the case of sericite schist, and both, in the case of chlorite-sericite schist. Both the metagabbro and the greenstone are metamorphosed igneous intrusions, with the gabbro having a more mafic composition and the greenstone having a more felsic composition. The graywacke is a complex, silicate-rich metasedimentary phase, though it is less altered than the other phases accessed by the Soudan boreholes. Finally, the most complex phase is the banded iron formation, which largely consists of alternating layers of hematite and chert or jasper, but also includes minor phases such as iron-rich chlorite, sulfides, and quartz.

In the East Drift, five boreholes were sampled. Three of these were horizontal: DDHs 960, 962, and 966. Two angled boreholes were sampled. One of the angled boreholes, DDH 933, was drilled at a 60-degree downward angle for $107 \mathrm{~m}$. This borehole was 
TABLE 1 | Physical characteristics of boreholes.

\begin{tabular}{|c|c|c|c|c|c|c|c|c|c|c|c|}
\hline DDH \# & DDH 920 & DDH 932 & DDH 933 & DDH 942 & DDH 944 & DDH 948 & DDH 951 & DDH 960 & DDH 962 & DDH 964 & DDH 966 \\
\hline Drift & West & West & East & West & West & East & West & East & East & West & East \\
\hline Angle (Deg.) & 0 & -50 & -60 & -55 & -50 & 55 & -50 & 0 & 0 & 0 & 0 \\
\hline Length (m.) & 276 & 102 & 107 & 130 & 125 & 63 & 144 & 84 & 86 & Unknown & 86 \\
\hline
\end{tabular}

drilled through chlorite schist before reaching pockets of banded iron formation and hematite ore; the deepest part of the borehole accesses a formation termed 'schist 'n' biff' (Peterson, 2019). This deeper formation comprises layers of chlorite schist, sericite schist, and iron formation and is commonly accessed through the East Drift, but rarely so in the West Drift Boreholes. The other borehole, DDH 948, was drilled at a 55-degree upward angle for $63 \mathrm{~m}$. This borehole accesses small pockets of hematite ore and banded iron formation, but it largely runs through chlorite and sericite schists.

Six boreholes (two horizontal, four downward-angled) were sampled in the West Drift. DDH 920, one of the horizontal boreholes, extends for $276 \mathrm{~m}$, far longer than the other boreholes sampled. This borehole largely accesses schist and banded iron formation; however, it is the only borehole to reach a pocket of greywacke and slate, part of the Ely Greenstone formations. Records of the rock accessed by the other horizontal borehole on the west drift, DDH 964, were not found. The four downwardangled boreholes sampled on the West Drift all access regions of crust with comparatively more hematite ore and banded iron formation than those on the East Drift. Still, they differ slightly amongst themselves with respect to the rocks they access. DDHs 932 and 951 primarily access chlorite schist with small pockets of banded iron formation and hematite ore interspersed. The portions of DDH 942 closest to the surface primarily access metagabbro and chlorite schist; in its deepest regions, the borehole runs through stretches of banded iron formation and hematite ore. DDH 944 accesses the most iron-rich lithologies, running primarily through banded iron formation in the shallow region and hematite ore in the deeper stretches.

\section{Borehole Water Chemistry Aqueous Geochemistry of Boreholes}

The water flowing from boreholes in the Soudan Mine was sampled sporadically over the course of 9 years. Regular analyses, performed at each timepoint for each borehole, include measurements of physical (temperature, $\mathrm{pH}$, and conductivity) and chemical (major cations and anions, minor cations, and trace elements) properties. Some timepoints include additional analyses of redox potential, dissolved oxygen, and an expanded suite of trace elements. These results have been compiled and averaged for each borehole and can be seen in Table 2. Full results broken down into individual timepoints and including all anions, cations, and trace elements can be found in the Supplemental Information (Supplementary Table S1).

The fluid flowing from all boreholes was found to be a calcium-sodium-chloride brine, though the concentration of total dissolved constituents $(<0.2$ micron $)$ varied from borehole to borehole (Table 2). The molar ratio of $\mathrm{Ca} / \mathrm{Cl}$ remained relatively consistent from sample to sample, ranging from 0.258 in $\mathrm{DDH} 920$ to 0.326 in $\mathrm{DDH} 944$ with no clear correlation with concentration. The $\mathrm{Ca} / \mathrm{Na}$ ratio varied more, ranging from 0.775 in the least saline fluid, $\mathrm{DDH} 960$, to 1.17 in a more saline sample. The $\mathrm{Ca} / \mathrm{Mg}$ ratio in borehole waters had a wide variation and showed the strongest correlation with borehole fluid strength. The smallest ratio was 3.33, found in a sample from DDH 920, while the largest ratio was 5.68, found in a sample from DDH 944. The less concentrated samples tended to have lower ratios, while more concentrated samples tended to have higher ratios.

Overall, the most saline brines flowed out of boreholes on the West Drift. On both the East and West drifts, the waters flowing out of boreholes drilled at a downward angle were more concentrated than those flowing out of horizontal boreholes or those drilled at an upward angle. Thus, the most saline brine is accessed by the boreholes drilled at downward angles on the West Drift; in order of least to most concentrated, that is DDHs 942, 951, 944, and 932.

Alkalinity concentrations (DIC) were highest in waters sampled within the East Drift and higher in horizontal and upward angled boreholes, reaching a maximum concentration of $43.5 \mathrm{mg} / \mathrm{L}$ in $\mathrm{DDH} 960$ and a minimum concentration of $0.1 \mathrm{mg} / \mathrm{L}$ in $\mathrm{DDH}$ 933. Sulfate concentrations were similarly highest in horizontal boreholes on the East Drift. Though lower in the downward-angled West Drift boreholes, sulfate was consistently detectable in all samples. Conversely, total iron concentrations were consistently highest in the downward-angled boreholes on the West Drift, reaching a maximum concentration of $121 \mathrm{mg} / \mathrm{L}$ in $\mathrm{DDH}$ 932, and consistently lower in the horizontal boreholes on the East Drift, with a minimum concentration of $0.06 \mathrm{mg} / \mathrm{L}$ in $\mathrm{DDH}$ 962. Nutrients, i.e., nitrogen, ammonia, and phosphate, were consistently below the analyses' margins of error when detectable.

\section{Stability of Borehole Water Chemistry Over Time}

Because we sampled many of these boreholes at multiple timepoints, we can track the stability of physical and chemical properties of these waters over time. The stability of temperature and of calcium and chloride concentrations in these boreholes is illustrated in Figure 2. Temperature was included to demonstrate the lack of apparent seasonal variation in water temperature. Though some variation $\left( \pm 0.5^{\circ} \mathrm{C}\right)$ in temperature can be seen, temperatures are overall quite similar from timepoint to timepoint and from borehole to borehole; overall, neither a long-term shift towards warmer or colder temperatures nor any seasonal temperature patterns can be seen. Calcium and chloride concentrations are included to demonstrate the 
TABLE 2 | Chemical characteristics of boreholes.

\begin{tabular}{|c|c|c|c|c|c|c|c|c|c|c|c|}
\hline DDH \# & DDH 920 & DDH 932 & $\begin{array}{l}\text { DDH } \\
933\end{array}$ & DDH 942 & DDH 944 & DDH 948 & DDH 951 & $\begin{array}{l}\text { DDH } \\
960\end{array}$ & DDH 962 & DDH 964 & $\begin{array}{l}\text { DDH } \\
966\end{array}$ \\
\hline \# Timepoints & 8 & 8 & 1 & 9 & 7 & 2 & 8 & 1 & 4 & 4 & 1 \\
\hline Temperature $\left({ }^{\circ} \mathrm{C}\right)$ & $10.7 \pm 0.5$ & $11.5 \pm 0.4$ & 10.7 & $11.0 \pm 0.2$ & $10.9 \pm 0.1$ & $12 \pm 1$ & $11.0 \pm 0.3$ & 11.1 & $11.2 \pm 0.5$ & $11.3 \pm 0.5$ & 11.2 \\
\hline $\mathrm{PH}$ & $6.2 \pm 0.8$ & $6.0 \pm 0.4$ & 3.7 & $6.3 \pm 0.4$ & $5.8 \pm 0.5$ & $6.8 \pm 0.3$ & $6.3 \pm 0.4$ & 6.7 & $6.4 \pm 0.4$ & $5.9 \pm 0.7$ & 4.7 \\
\hline Conductivity (mS) & $17 \pm 7$ & $130 \pm 30$ & 28 & $100 \pm 20$ & $110 \pm 40$ & $11.4 \pm 0.2$ & $110 \pm 30$ & 7.51 & $30 \pm 4$ & $80 \pm 30$ & 24.6 \\
\hline Redox (mV) & $-70 \pm 50$ & $-200 \pm 100$ & - & $-500 \pm 200$ & $-200 \pm 100$ & - & $-200 \pm 100$ & - & -96 & $-70 \pm 40$ & - \\
\hline $\begin{array}{l}\text { Total Dissolved Solids } \\
(\mathrm{ppm})^{\star}\end{array}$ & $9600 \pm 100$ & $116,000 \pm 3,000$ & 24,000 & $76,000 \pm 2000$ & $97,000 \pm 1,000$ & $8,760 \pm 50$ & $80,000 \pm 2000$ & 5,580 & $19,100 \pm 500$ & $52,000 \pm 3,000$ & 21,000 \\
\hline $\mathrm{Na}(\mathrm{mM})$ & $48.9 \pm 0.8$ & $570 \pm 20$ & 130 & $380 \pm 10$ & $490 \pm 20$ & $43.5 \pm 9$ & $420 \pm 10$ & 34.4 & $98 \pm 3$ & $250 \pm 20$ & 107 \\
\hline $\mathrm{Mg}(\mathrm{mM})$ & $13.5 \pm 0.2$ & $116 \pm 4$ & 28.4 & $81 \pm 3$ & $101 \pm 3$ & $11.9 \pm 0.1$ & $87 \pm 4$ & 6.91 & $22.2 \pm 0.4$ & $63 \pm 1$ & 24.6 \\
\hline $\mathrm{Ca}(\mathrm{mM})$ & $45.9 \pm 0.6$ & $610 \pm 20$ & 116 & $400 \pm 20$ & $500 \pm 10$ & $43.0 \pm 0.2$ & $390 \pm 10$ & 26.7 & $100 \pm 2$ & $270 \pm 10$ & 110 \\
\hline Alk (mM) & $0.7 \pm 0.5$ & $0.4 \pm 0.1$ & 0.004 & $0.5 \pm 0.2$ & $0.5 \pm 0.4$ & $1.480 \pm 0.002$ & $0.6 \pm 0.1$ & 0.72 & $1.4 \pm 0.2$ & $0.4 \pm 0.3$ & 1.41 \\
\hline $\mathrm{Cl}(\mathrm{mM})$ & $172 \pm 3$ & $2080 \pm 40$ & 440 & $1,370 \pm 30$ & $1750 \pm 20$ & $157 \pm 2$ & $1,430 \pm 30$ & 97.3 & $341 \pm 8$ & $930 \pm 60$ & 375 \\
\hline $\mathrm{SO} 4$ (mM) & $0.08 \pm 0.03$ & $0.7 \pm 0.4$ & 1.06 & $0.5 \pm 0.2$ & $0.8 \pm 0.3$ & $0.92 \pm 0.03$ & $0.7 \pm 0.4$ & 2.82 & $0.7 \pm 0.3$ & $0.8 \pm 0.3$ & 1.67 \\
\hline $\mathrm{Fe}(\mathrm{mM})$ & $0.5 \pm 0.1$ & $2.1 \pm 0.1$ & 0.004 & $1.8 \pm 0.6$ & $1.7 \pm 0.1$ & $0.04 \pm 0.02$ & $1.3 \pm 0.4$ & 0.098 & $0.2 \pm 0.2$ & $0.6 \pm 0.1$ & 0.276 \\
\hline Si (mM) & $0.12 \pm 0.02$ & $0.13 \pm 0.05$ & 0.157 & $0.14 \pm 0.06$ & $0.11 \pm 0.04$ & $0.118 \pm 0.004$ & $0.11 \pm 0.07$ & 0.121 & $0.12 \pm 0.01$ & $0.10 \pm 0.01$ & 0.121 \\
\hline $\mathrm{Br}(\mathrm{mM})$ & $0.42 \pm 0.01$ & $4.94 \pm 0.09$ & 1.05 & $3.2 \pm 0.1$ & $4.1 \pm 0.1$ & $0.38 \pm 0.01$ & $3.38 \pm 0.08$ & 0.22 & $0.76 \pm 0.04$ & $2.3 \pm 0.1$ & 0.856 \\
\hline $\mathrm{NH} 4$ (mM) & - & - & - & $0.06 \pm 0.01$ & - & - & $0.04 \pm 0.06$ & - & 0.064 & 0.095 & - \\
\hline NO3 (mM) & $0.0003 \pm 0.0005$ & $0.001 \pm 0.003$ & 0.01 & $0.006 \pm 0.007$ & $0.001 \pm 0.002$ & $0.0003 \pm 0.0004$ & $0.004 \pm 0.008$ & - & $0.003 \pm 0.005$ & $0.005 \pm 0.006$ & - \\
\hline$P(\mathrm{mM})$ & $0.0001 \pm 0.0001$ & $0.002 \pm 0.004$ & 0.003 & $0.1 \pm 0.2$ & $0.0008 \pm 0.0008$ & - & $0.1 \pm 0.1$ & 0.0002 & $0.01 \pm 0.02$ & $0.08 \pm 0.08$ & 0.0002 \\
\hline
\end{tabular}

For measurements taken at multiple timepoints, the average value was provided along with the standard deviation.

*Sum of all measured inorganic aqueous constituents after 0.2 micron filtration in $\mathrm{mg} / \mathrm{L}$ or ppm. 


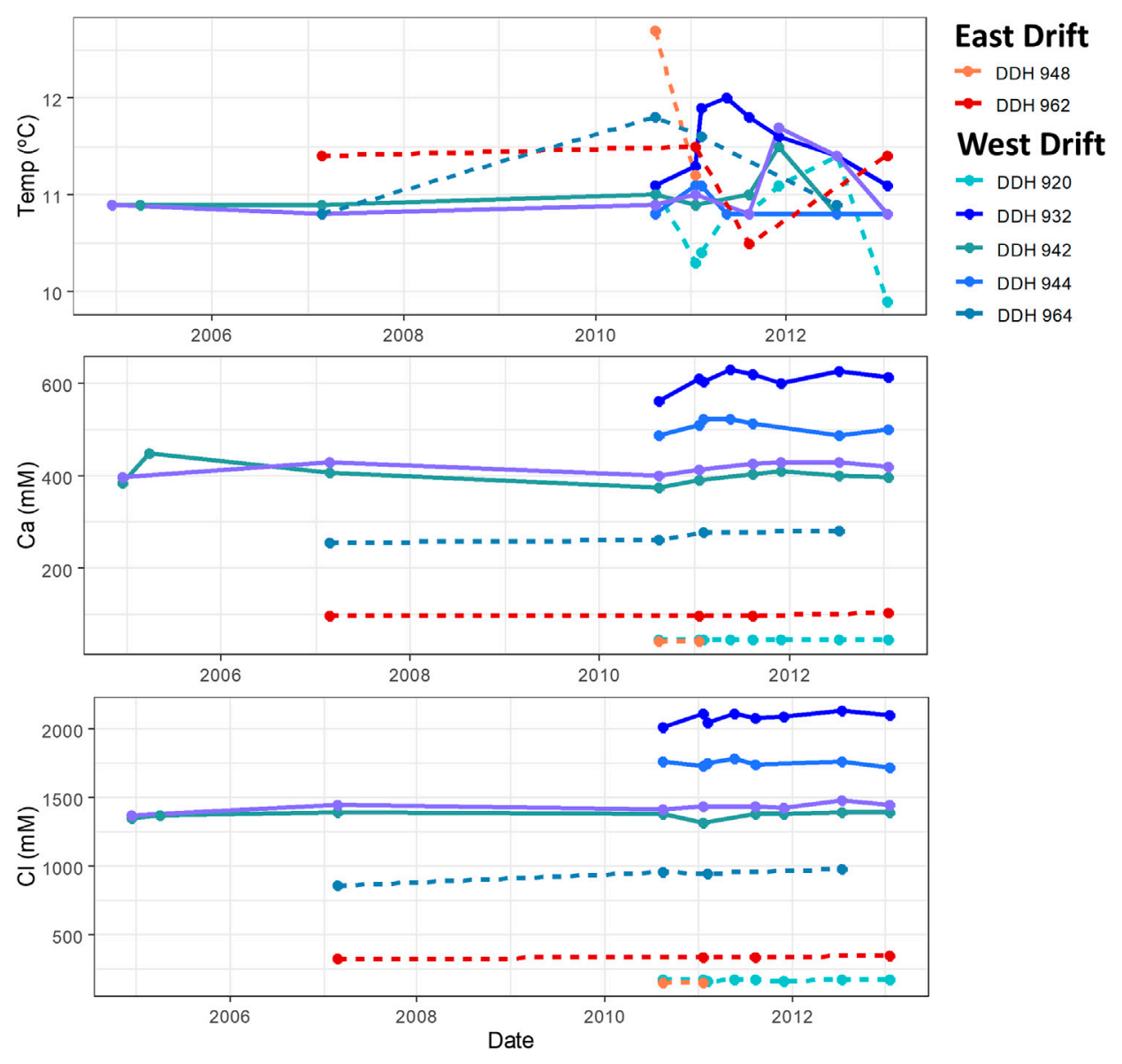

FIGURE 2 | Stability of the temperature and major iron concentrations in Soudan boreholes. East drift boreholes are shown in shades of red, while west drift boreholes are shown in shades of blue. Solid lines indicate boreholes drilled at a downward angle, while dashed lines indicate horizontal or upward angled boreholes.

stability of conservative ion concentrations over time. Little variation (roughly $3 \%$ relative standard deviation) can be seen in the concentrations of these elements in a given borehole-neither a long-term trend nor any seasonal variation is present. Additionally, this stability can be seen for both the highly concentrated and less concentrated borehole waters. This stability holds true for other conservative elements as well, including major cations like sodium and magnesium and minor ionic solutes like potassium. Figure 2 also highlights the spatial trends discussed in the previous section: higher major ion concentrations are observed in both the downward-angled boreholes and on the West drift, so the most concentrated groundwaters are found in the downward-angled boreholes on the West drift.

The temporal stability of the concentrations of some redoxsensitive solutes can be seen in Figure 3. Sulfate concentrations have a definitive, decreasing long-term trend in all boreholes; they also show some variation from timepoint to time-point (about $40 \% \mathrm{RSD}$ in the most saline boreholes). Iron concentrations in all boreholes are stable over time with regard to long-term trends; however, some variation can be seen between samples. Manganese concentrations remain stable both in point-to-point variation and long-term trends. Spatially, Figure 3 highlights that the highest sulfate concentrations are found in the East Drift while West drift concentrations are generally about $0.5 \mathrm{mM}$ lower. In the downward-angled boreholes on the West Drift, little spatial variation occurs-concentrations in a given timepoint are largely consistent between boreholes. Iron and manganese concentrations show the opposite trend: concentrations are highest in the downward-angled boreholes and on the West drift; concentrations have higher and more consistent spatial variation than temporal variation.

\section{Hydrogen and Oxygen Isotopes ${ }^{2} \mathrm{H}$ and ${ }^{18} \mathrm{O}$ Values in Borehole Water}

Water from 27th-level boreholes was sampled for hydrogen and oxygen isotopes periodically over the course of 2 years. Boreholes were sampled from both the East and West drifts, spanning downward, horizontal, and upward-angled drilling directions. $\delta^{18} \mathrm{O}$ and $\delta^{2} \mathrm{H}$ values for these samples can be seen plotted against a regression for local meteoric water isotopes in Figure 4. Generally, the samples cluster into two broad groups: samples 

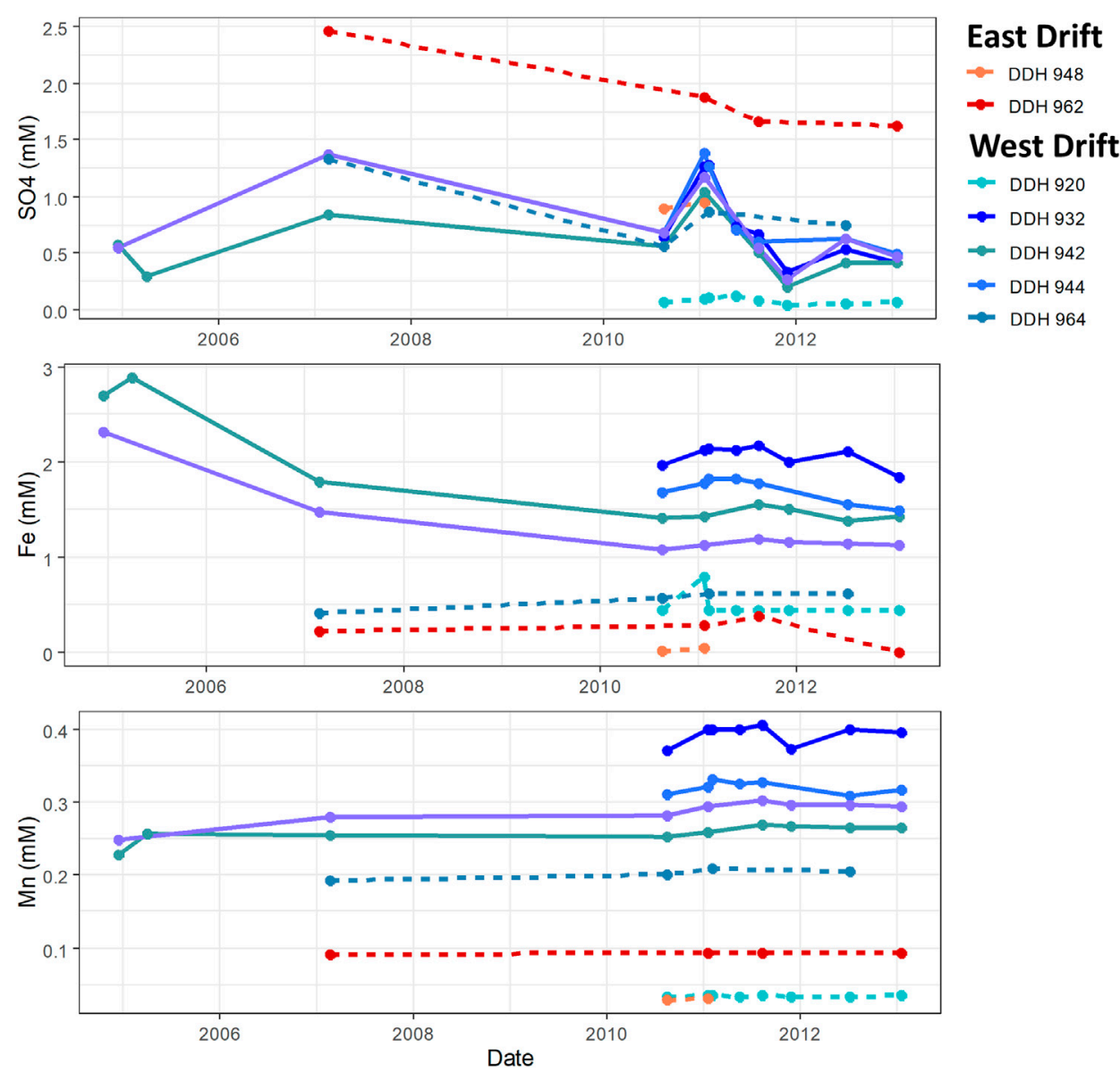

FIGURE 3 | Stability of the concentration of redox-sensitive solutes in Soudan boreholes. The Fe and Mn concentrations shown are of total Fe and total Mn, respectively. East drift boreholes are shown in shades of red, while west drift boreholes are shown in shades of blue. Solid lines indicate boreholes drilled at a downward angle, while dashed lines indicate horizontal or upward angled boreholes.

from downward boreholes in the West Drift, which are less depleted in both ${ }^{2} \mathrm{H}$ and ${ }^{18} \mathrm{O}$, and almost all other samples, which are more depleted in those isotopes. All samples from the former group plot above the meteoric water regression, which is characteristic of isolated samples from deep silicate aquifers (Kloppmann et al., 2002). Samples from the latter group include all boreholes on the East Drift and a horizontal borehole from the West Drift. These samples mainly plot on the meteoric water line, though some samples plot slightly below it. The one exception to this grouping is DDH 964, a horizontal borehole from the West Drift. $\delta^{18} \mathrm{O}$ and $\delta^{2} \mathrm{H}$ values from this borehole group closer to those from the West Drift downward-angled boreholes than to those from the other remaining boreholes. A figure showing the Soudan water isotope values grouped by individual borehole can be found in the supplemental information (Supplementary Figure S3).

$\delta^{2} \mathrm{H}$ measurements of the water from the downwardangled West Drift borehole samples range from a $-75.12 \%$ in DDH 951 to $-61.86 \%$ in $\mathrm{DDH} 932 . \delta^{18} \mathrm{O}$ measurements in these samples range from $-11.38 \%$ in $\mathrm{DDH} 932$ to $-10.70 \%$ in $\mathrm{DDH}$ 951. The degree of separation between these samples and the regional meteoric water line seems to correlate with salinity-the most saline borehole in this group, $\mathrm{DDH}$ 932, is the furthest from the meteoric water regression line; DDHs 942 and 951 are both less saline and closer to the meteoric water regression. DDH 964, while horizontal, has much more saline water than all boreholes except for this group of downward-angled boreholes in the West Drift. DDH 964 also has $\delta^{18} \mathrm{O}$ and $\delta^{2} \mathrm{H}$ water isotope ratios closer to this group of downward angled boreholes than to the less saline boreholes sampled in this study.

\section{Tritium in Borehole Water}

Water samples from DDH 920, a horizontal borehole on the West Drift, and DDHs 932 and 942, downward-angled boreholes on the West Drift, were tested for tritium abundance. For all boreholes, a single timepoint was tested. Tritium concentrations were below the limit of detection in water samples from DDHs 920 and 942. The water sampled from DDH 932 was too saline for analysis; however, based on the observed correlation between salinity and degree of isolation for other borehole water measurements, it seems 


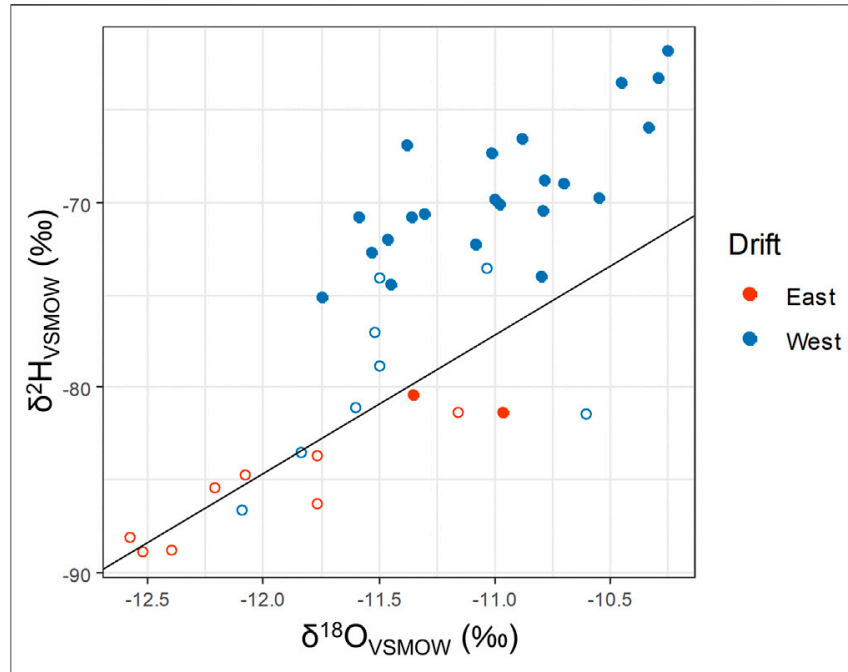

FIGURE 4 | Water isotopes of Soudan borehole samples. Filled circles represent samples taken from boreholes drilled at a downward angle relative to the mine floor, while open circles represent samples drilled at a horizontal or upward angle. The black line shows local meteoric water regression calculated from Ely, MN, United States precipitation sampled between April and November 1996.

unlikely that water from DDH 932 would have a higher tritium concentration than DDHs 920 or 942 -it is likely that tritium abundance in this borehole would also be below the limit of detection. Full results of the tritium analyses, including standard deviation, are given in the Supplementary Information (Supplementary Table S2).

\section{DISCUSSION}

\section{Aqueous Geochemistry of the Soudan Mine Groundwater}

As the field of deep biosphere research has matured, several studies have highlighted the utility of using a thorough lithological and geochemical description of a site to guide microbiological investigations (Lollar et al., 2019; Osburn et al., 2019). To augment past and future research into the microbial communities at the Soudan Mine, we studied the geochemistry and hydrology of the Soudan groundwaters, including the sources of salinity, the stability of subsurface mixing, and the relative isolation of waters accessed by the mine. These Soudan-specific conclusions were then evaluated in the broader context of other Canadian Shield and deep biosphere research sites.

There are many similarities across the fractured-rock groundwater flowing from all Soudan Mine boreholes. The waters are rich in calcium, sodium, and chloride; the temperature of all borehole waters sampled in this study varies little and averages between $10.5-12^{\circ} \mathrm{C}$. The $\mathrm{Ca}^{2+}: \mathrm{Cl}^{-}$ratio is largely consistent among boreholes. The ratios of chloride and all three major cations, $\mathrm{Na}^{+}$, $\mathrm{Ca}^{2+}$, and $\mathrm{Mg}^{2+}$ are also similar from borehole to borehole. The consistency of these ratios indicates that the source of salinity is likely the same from borehole to borehole. The constant ratio of the two dominant ions, $\mathrm{Ca}^{2+}$ and $\mathrm{Cl}^{-}$, is compared for all water samples in Figure 5. Also compared are salinity, represented by chloride concentration, and relative deuterium excess (RDE), a measure of how much a water sample's isotope values deviate from the local meteoric water line (LMWL). The equation used to calculate RDE is as follows (Kloppmann et al., 2002):
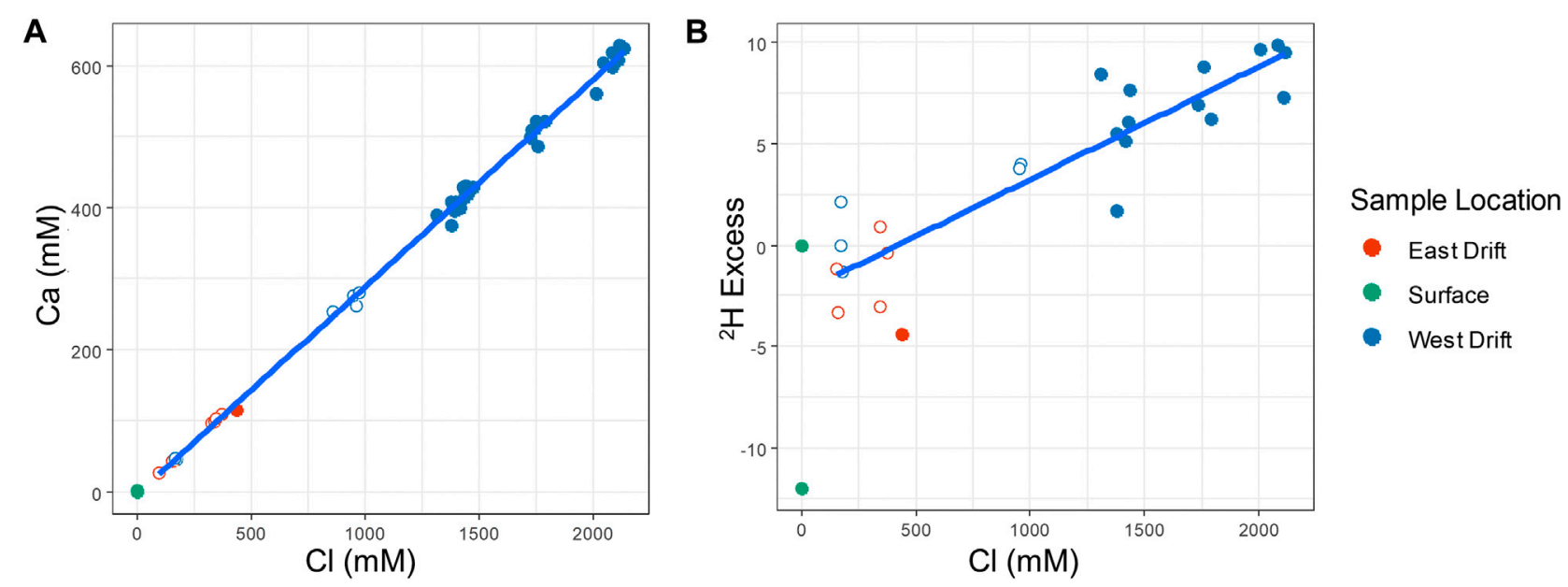

FIGURE 5 | Diagrams showing mixing in Soudan groundwaters. (A) $\mathrm{Ca}^{2+}$ concentrations versus $\mathrm{Cl}^{-}$concentrations in Soudan borehole water, with the blue line indicating a regression based on these values $\left(R^{2}=0.9979\right)$. Filled red or blue points represent samples taken from downward angled boreholes, while open red or blue points indicate samples taken from horizontal or upward boreholes. Green points are surface water samples taken from a spring in the town of Soudan, MN and from the nearby Lake Vermillion. (B) Deuterium excess, as compared to Ely, $\mathrm{MN}$ precipitation, versus $\mathrm{Cl}^{-}$concentrations in Soudan borehole water, with the blue line indicating a regression based on these values $\left(R^{2}=0.8122\right)$. Filled red or blue points represent samples taken from downward angled boreholes, while open red or blue points indicate samples taken from horizontal or upward boreholes. Green points indicate deuterium excess of Lake Vermillion sample and an average of Ely, MN precipitation deuterium excess, which is by definition 0 . 


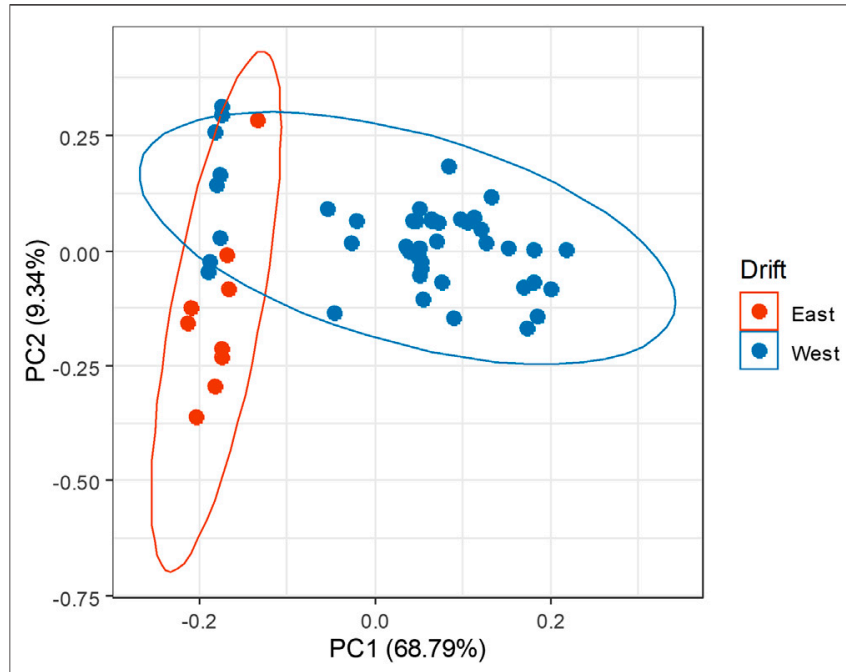

FIGURE 6 | Principal component analysis of Soudan borehole waters based on geochemistry data. PCA was conducted in R using the prcomp() command and plotted using the ggfortify package. After the PCA, the points were plotted with groupings based on the drift in which the boreholes were drilled.

$$
R D E=\delta^{2} H-a \delta^{18} \mathrm{O}-b
$$

where $\mathrm{a}$ and $\mathrm{b}$ are constants taken from the local meteoric water regression. Taken as a whole, Figure 5 shows that all Soudan groundwaters derive their salinity from a single source and are diluted by water with a RDE resembling that of surface water. Relative isolation from surface waters, for which RDE can be used as a proxy, increases with salinity. The same comparison of salinity with RDE, grouped by individual borehole, can also be seen in the supplemental information (Supplementary Figure S4).

The temporal changes in the salinity of a borehole would indicate whether the mixing of these two waters varies over time. Figure 2 shows the stability of temperature and $\mathrm{Ca}^{2+}$ and $\mathrm{Cl}^{-}$ concentration between 2004 and 2013. Little variation is seen in these values over this time period; the same is true for the other major cations, $\mathrm{Na}^{+}$and $\mathrm{Mg}^{2+}$. Though slight changes in subsurface mixing seem to occur, no long-term pattern is observed and there seems to be far less temporal variation in water composition than spatial variation. The stability of redoxsensitive solutes (sulfate, total $\mathrm{Fe}$, and total $\mathrm{Mn}$ ) was also measured, as seen in Figure 3. Though the measurements of total $\mathrm{Mn}$ and total Fe did not differentiate between their different valence states, it was assumed that the aqueous phases consisted only of their most soluble species, $\mathrm{Mn}^{2+}$ and $\mathrm{Fe}^{2+}$. Oxidation of $\mathrm{Mn}_{\mathrm{aq}}^{2+}$ and $\mathrm{Fe}_{\mathrm{aq}}^{2+}$ leads to the precipitation of insoluble manganese and iron hydroxides in oxic waters of neutral $\mathrm{pH}$. Thus changes in the concentrations of these elements would indicate changes in the overall redox potential of these waters. The presence of these elements in relatively high concentrations in borehole fluid indicates that these waters are likely anoxic. For most boreholes, $\mathrm{Mn}$ and $\mathrm{Fe}$ concentrations varied little over the sampling period. The starkest differences were seen between the first and third timepoints for DDHs 942 and 951; this may be attributable to changes in sampling technique between these timepoints: the water was initially sampled from a pool around the borehole aperture; after the second timepoint, samples were taken at the mouth of the borehole. In contrast, concentrations of sulfate decreased over time with some fluctuation from timepoint to timepoint. This may be explained by a shift in redox conditions or an increase in microbial sulfate reduction over time; however, the consistent concentrations of manganese and iron cast doubt on an overall change in the down-borehole redox state. It is also possible that fluctuating sulfate concentrations are an artifact of inconsistencies in analytical technique.

The temporal trends of these redox-active species can be interpreted in the context of Soudan's down-borehole fluid microbial communities determined by metagenomic analyses (Sheik et al., 2021). Diverse genes encoding for enzymes in sulfur reduction pathways were present in the assembled metagenomes, as were a few genes encoding for enzymes in sulfur oxidation pathways. The genetic potential for a wide variety of sulfur cycling genes suggests that long-term fluctuations in sulfur reduction rates are caused by changes in the abundance or activity of sulfur cycling community members. Sheik et al., 2021 also highlighted the presence of a number of genes related to iron and manganese reduction. While the borehole fluid itself is unlikely to contain any oxidized iron or manganese that could be used as a substrate by the microbes that mediate metal reduction, lithologies like the hematite ore and banded iron formation are rich in ferric iron. Thus, the presence of these genes in borehole fluid communities points to the interactions between these microbial communities and the fractured rock networks that contain them.

A major goal of this geochemical study is to guide future research into the microbial communities in the Soudan groundwaters by identifying the most isolated fractures. These have the potential to host the most distinct microbial communities in the mine, as they have been most able to develop without surface influence over long periods of time. As seen in the mixing diagram (Figure 5), the most isolated waters within Soudan seem to have the highest concentrations of dissolved salts and the most distinct isotope ratios. A principal component analysis (PCA) was used to determine whether any other groupings could be observed among the water samples. The PCA shows that spatial parameters relating to where they were drilled in the mine drive sample similarity. Strong separation is observed between boreholes on the East and West drift (Figure 6), as well as between those drilled at a downward angle and those drilled at horizontal or upward angles (Supplementary Figure S5). This geochemical data can also be evaluated in the context of the regional geology. Deformation of the West Drift protected the deep fractures from infiltration by surface waters; no such deformation occurred on the East Drift, leading to a network of vertical fractures that may have facilitated the slow dilution of groundwaters by surface runoff. The grouping of downward-angled boreholes on the West Drift, DDHs 932, 942, 944, and 951, has been shown to be distinct from all other sampled boreholes through this principal component analysis. These boreholes are of particular interest due isolation afforded by the configuration of the surrounding rock. They are likely the most isolated waters in the mine and of the highest interest for future microbial studies. A recent study used metagenomic 

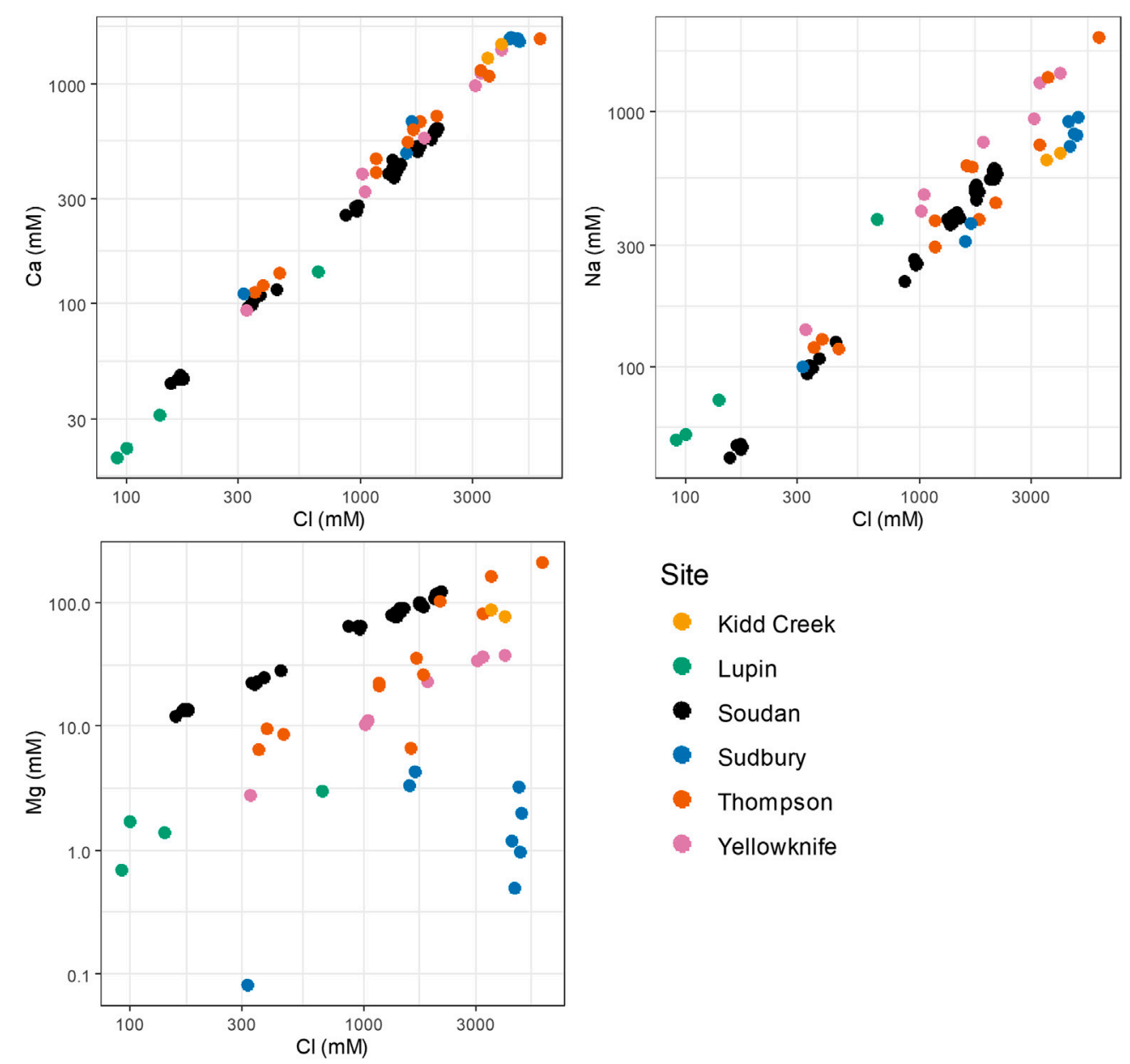

Site

Kidd Creek
Lupin
Soudan
Thompson
Yellowknife

FIGURE 7 | Variation in major ion concentrations among Canadian Shield sites. A map showing the locations of these sites can be seen in Supplementary Figure S6. Kidd Creek (Timmins, ON, Canada) data were published in (Lollar et al., 2019). Lupin (Nunavut Territory, Canada) data were published in (Onstott et al., 2009). Sudbury Basin (ON, Canada) and Yellowknife (Northwest Territiries, CA) data were published in (Fritz and Frappe, 1982) and (Frape et al., 1984). Thompson (MB, Canada) data were published in (Fritz and Frappe, 1982), (Frape et al., 1984), and (Telling et al., 2018).

sequencing to investigate the communities in the West drift boreholes, comparing these four downward-angled holes as well as the horizontal DDHs 920 and 964 (Sheik et al., 2021). The microbial communities in the downward-angled boreholes were less diverse and less evenly distributed with regard to alpha diversity than those in the horizontal communities, though there were distinct differences even between boreholes with similar salinities. Though isolation and salt concentration both appear to play major roles in determining community composition, lithology of the surrounding rock and connectivity between different fractures also likely control local variations.

\section{Soudan in the Context of the Canadian Shield}

The groundwaters accessed by Soudan Mine boreholes have a similar geochemistry to those found in deep boreholes across the Canadian Shield. Such waters are often isolated from the surface and have long been interpreted to have gained their brine composition from long term rock-water interactions. Such brines create distinct habitats for subsurface microbes. The geochemistry of Soudan brines can be interpreted in the broader context of these Canadian Shield waters. Canadian Shield brines were first described as $\mathrm{Ca}-\mathrm{Cl}$ type brines with a distinctive water isotope composition (Fritz and Frape, 1982). An expanded study surveying a wider range of sites found that the $\mathrm{Ca} / \mathrm{Na}$ ratios in these waters was variable, but in general a Ca-Na$\mathrm{Cl}$ type brine was characteristic of Canadian deep shield waters (Frape et al., 1984).

It has long been suspected that the geochemistry of these waters is dependent on long-term rock-water interactions. Strontium isotopes serve as one example of this-because strontium often substitutes for calcium in rock-forming minerals, a comparison of water and rock strontium isotopes can determine the degree to which water-rock interactions are responsible for the overall calcium concentration. The strontium isotopes on Canadian Shield brines have been shown to match those of the feldspars in the associated host rocks, providing 
evidence for long-term rock-water interactions (McNutt et al., 1990). Strontium isotope ratios in the deepest waters have a narrower range than those of surface water and specifically match the ratios found in both plagioclase and in the secondary gypsum and calcite precipitated on the walls of fractures (Franklyn et al., 1991). Water isotope ratios also support long-term rock-water interactions. Modeling studies show that the dissolution of smectites and feldspars and the precipitation of goethite and kaolinite in deep rock groundwaters should lead to the depletion of ${ }^{18} \mathrm{O}$ relative to ${ }^{2} \mathrm{H}$ (Kloppmann et al., 2002). These altered water isotope values are found in the most isolated parts of Soudan Mine (Figures 4, 5) and have long been found across the Canadian Shield (Fritz and Frape, 1982; Frape et al., 1984; Kelly et al., 1986; Lollar et al., 2019).

Although water-rock interactions have certainly contributed to the overall composition of these waters, they are likely not their only source of salinity. End-member $\mathrm{Ca}-\mathrm{Cl}$ brines derived solely from rock-water interactions have lower concentrations of total dissolved constituents ( $<0.2$ micron) than those found in the Canadian Shield waters, suggesting that additional processes contribute to their chemical composition (Bucher and Stober, 2011). Though there is debate as to what the specific source of additional salinity could be, the fluid chemistry observed today is considered the result of a highly saline brine altered through rockwater interaction and diluted to varying degrees by meteoric surface water (Kelly et al., 1986; Bottomley et al., 2002). One suggested source of salinity is ancient marine water, long trapped below the surface (Bottomley et al., 1994; Starinsky and Katz, 2003). An alternate explanation is that the brines are the result of the cooling and dilution of metamorphic or hydrothermal fluids trapped in the subsurface. This is supported by a study of fluid inclusions in the Canadian Shield, which found that the chemistry of these inclusions agrees with that of the brines (Kelly et al., 1986). Regardless of their origin, concentration through either cryogenic means or evaporation has been suggested as a factor impacting overall brine composition (Bottomley et al., 1999; Starinsky and Katz, 2003). Though a more detailed characterization of Canadian Shield waters suggested that cryogenic alteration only affected shallower, less concentrated waters rather than deeper brines (Stotler et al., 2012).

A comparison of the Soudan Mine groundwaters to those of other Canadian Shield sites can be seen in (Figure 7), while a map showing the location of these sites can be found in the Supplemental Information (Supplementary Figure S6). The $\mathrm{Ca}-\mathrm{Cl}$ concentrations for Soudan Mine scale at a similar rate with all other sites examined - the linear regression of $\mathrm{Cl}^{-}$ concentrations versus $\mathrm{Ca}^{2+}$ concentrations in these water samples has a coefficient of determination $\left(\mathrm{R}^{2}\right)$ equal to 0.9703. This may indicate that calcium concentration in the most concentrated brines is controlled by the same process, e.g., plagioclase dissolution (McNutt et al., 1990; Franklyn et al., 1991). A weaker correlation is observed for $\mathrm{Na}^{+}: \mathrm{Cl}^{-}$and $\mathrm{Mg}^{2+}: \mathrm{Cl}^{-}$among sites: a regression of $\mathrm{Cl}^{-}$concentrations vs. $\mathrm{Na}^{+}$ concentrations has $R^{2}$ equal to 0.8093 , while a regression of $\mathrm{Cl}^{-}$ versus $\mathrm{Mg}^{2+}$ has $R^{2}$ equal to 0.1233 . The $\mathrm{Mg}^{2+}$ concentrations in the Soudan Mine groundwaters appear to be an outlier-Soudan has the highest ratio of $\mathrm{Mg}^{2+}$ to overall salinity out of any of the sites. Local lithology may account for these differences, as it is known to have a controlling effect on the prevalence of major cations in continental fractured-rock aquifers, with high $\mathrm{Ca}^{2+}$ and $\mathrm{Mg}^{2+}$ concentrations caused by reactions with mafic rocks and high $\mathrm{Na}$ concentrations caused by reactions with granitic rocks (Frape et al., 1984; Bucher and Stober, 2011). These trends have held true for waters outside of the Canadian Shield. An analysis of waters found below mines in South Africa found that two major groups of waters were found, with groupings controlled by rock chemistry (Onstott et al., 2006). These differences in water chemistry, then, are indicative of differences in rock chemistry as well. The uniquely high concentrations of $\mathrm{Mg}^{2+}$ in the Soudan waters likely highlight differences in its lithological composition, providing a novel subsurface environment for microbial populations. Comparisons of even relatively non-reactive elements between sites can be instrumental in selecting sites for future investigations into deep life.

\section{Geochemical Variation Between Deep Biosphere Sites}

Many studies have focused on the origins and composition of the Canadian Shield groundwaters, but less focus has been given to the microbial communities living within them. Early research into the shield brines suggests that a metabolically active biome is present. Methane isotopes provide evidence for microbial activity and are distinct from those generated by abiotic thermogenic processes (Sherwood Lollar et al., 1993). Further work exploring the isotopes and abundance of hydrocarbons in shield gasses and waters has complicated this picture but indicated methanogens are likely present in many Canadian Shield aquifers (Sherwood Lollar et al., 2002, Sherwood Lollar et al., 2006, Sherwood Lollar et al., 2008; Giunta et al., 2019). Despite this evidence for microbial life below the Canadian Shield, research explicitly focused on the microbiomes of these shield aquifers was not published for more than a decade after the early methane study. One of the earliest studies to use genomic techniques to characterize the microbes in the Canadian Shield's deep biosphere focused on the Lupin Mine in Nunavut Territory (Onstott et al., 2009). Water isotope data from this site, however, indicates these waters were unlikely to be from the deepest, most concentrated brines found on the shield (Stotler et al., 2009). The pace of research focused on the Canadian Shield has increased recently, as incubations from the Thompson Mine in Manitoba were used to measure the rate of hydrogenotrophic metabolisms in deep waters (Telling et al., 2018).

At the Kidd Creek Mine, Ontario, Canada, some of the most isolated waters on earth have been discovered (Holland et al., 2013). Geochemical measurements indicate that these waters host an active sulfur cycle capable of sustaining an isolated lithotrophic microbial community (Li et al., 2016). Microbial cell counts confirmed the existence of a microbial community at this site, while most probable number experiments indicated a robust anaerobic community including sulfate reducing bacteria (Lollar et al., 2019). These researchers have indicated that genomic characterization of the communities in these waters is ongoing. These efforts are proof of the efficacy of sustained 
research at a single site, which is essential to detail both a microbiological and a geochemical picture of subsurface life.

Still, comparisons of the research efforts focused on the deep continental biomes within the Canadian Shield to those focused on other areas with old continental crust and isolated waters show that the Canadian Shield is understudied. The Fennoscandian Shield is an example of a similarly old region of continental crust that has received far more study. This shield also contains similar $\mathrm{Na}-\mathrm{Ca}-\mathrm{Cl}$ brines with water isotopes depleted in ${ }^{18} \mathrm{O}$ (or enriched in ${ }^{2} \mathrm{H}$ ) relative to the GMWL, suggesting a similar origin and evolution process (Nurmi et al., 1988; Nordstrom et al., 1989). As with the Canadian Shield, studies of the methane contained in aquifers within the Fennoscandian Shield indicate partial microbial origin (Sherwood Lollar et al., 1993). Some of the earliest studies published on the deep biosphere focused on the enrichment of anaerobic bacteria from Fennoscandian Shield waters (Szewzyk et al., 1994). This was followed with a robust research program focused on the deep biosphere, with several sites receiving detailed geochemical and microbiological characterization.

The Äspö Hard Rock Laboratory, initially built to research disposal methods for nuclear waste, is a Fennoscandian Shield site with a great deal of research into subsurface hydrology, geochemistry, and microbiology. These studies include some of the earliest amplicon-based characterization of microbial communities in the subsurface (Pedersen et al., 1996; Pedersen, 1997). The microbial community has also been studied through innovative in and ex situ incubations (Ekendahl et al., 2003; Nielsen et al., 2006). This earlier work paved the way for modern genomic studies which have used metagenomic and metatranscriptomic methods to look at subsurface life below Äspö. Metagenomic sequencing has shown that the dominant community metabolisms likely change with depth, with heterotrophs more common in shallower groundwaters while deeper communities consist largely of lithotrophic and autotrophic microbes (Wu et al., 2016). Another sequencing study looking at community composition in these groundwaters, found that taxonomic diversity decreased with isolation and depth (Hubalek et al., 2016). Many taxa found in the deepest waters are thought to rely on nitrate and iron reduction, demonstrating the importance of the cycling of inorganic substrates in the subsurface (Lopez-Fernandez et al., 2018a). Through several decades of sustained research, these scientists were able to gain a detailed understanding of life in these fracture networks.

The Fennoscandian Shield also hosts the Outokumpu Deep Drilling Project, a research borehole drilled to reach waters with a subsurface residence time over $20 \mathrm{Ma}$ (Kietäväinen et al., 2014). Geochemical studies confirmed that the deepest waters accessed by this borehole are characteristic of the chloride brines found across the Fennoscandian Shield (Ahonen et al., 2011; Kietäväinen et al., 2013). Characterization of the microbial community at Outokumpu was first done by amplicon sequencing in conjunction with geochemical characterization of waters and gasses (Itävaara et al., 2011). It has also been subject to thorough metagenomic analyses (Purkamo et al., 2016). As with Äspö, Outokumpu demonstrates the power of sustained subsurface research, evidencing the need for such long-term projects in the Canadian Shield.
The Kaapvaal Craton, primarily located in South Africa, contains older crust and similarly isolated waters. Mines in this region host boreholes that access deep chloride brines, though waters tend to be hotter and with isotope ratios plotting on or to the right of the GMWL (Duane et al., 1997). More recent studies found some brines with water isotopes to the left of the GMWL, aligning with models of lowtemperature alteration towards waters resembling those in the Canadian or Fennoscandian shields; thus, water isotopes in this region may not be as reliable an indicator of isolation (Onstott et al., 2006). Regardless, there has been a robust research program focused on the deep biosphere below the Kaapvaal Craton. Decades of research began with a comparison of the organisms in this region to some from early sites for deep biosphere research (Baker et al., 2003). Early research in this region included both amplicon-based studies of community genomics (Moser et al., 2003; Moser et al., 2005) and geochemical analyses of fracture water and gases (Kieft et al., 2005; Lin et al., 2005; Moser et al., 2005). Building on this initial foundation, deep biosphere focused research in this region has since uncovered unique and vital milestones, pushing the field forward. This includes the characterization of a subsurface ecosystem with just a single species (Lin et al., 2006; Chivian et al., 2008) as well as proof of the presence of multicellular eukaryotes in microoxic fracture waters several kilometers below the surface (Borgonie et al., 2011; Borgonie et al., 2015). Recent work from the region has shed light on the specific pathways through which carbon moves through the subsurface (Simkus et al., 2016; Magnabosco et al., 2018).

This is by no means a comprehensive review of the work conducted in either region; rather, it is meant to highlight the results obtained from a sustained focus on deep life in these ancient, isolated waters. Such a focus on the Canadian Shield could have a similarly transformative impact; the Soudan Mine serves as an ideal site for such work: its waters are both characteristic of those found across the Canadian Shield and unique, due to their high magnesium concentrations. Early pyrosequencing work confirmed the existence of microbial communities in Soudan's groundwaters (Edwards et al., 2006), while recent metagenomic sequencing indicated that the fracture network contains a microbial community capable of cycling H, C, N, and S (Sheik et al., 2021). The hematite ore body and banded iron formations make the Soudan Mine well positioned for characterization of microbial iron metabolisms. Several such organisms have been isolated from the site, indicating the potential for a diverse and distinct community of these organisms in the subsurface (Bonis and Gralnick, 2015; Badalamenti et al., 2016). Further work characterizing the site could reveal possible differences in the microbial community attributable to these geologic factors.

To better understand Soudan in the context of the deep biosphere, then, the chemistry of conservative ions in these waters can once again be compared between sites. In Figure 8, the behavior of conservative ions with respect to overall salinity (as indicated by $\mathrm{Cl}^{-}$) are compared between Soudan and other locations where research into the deep biosphere has been conducted. Data was selected from papers including both 

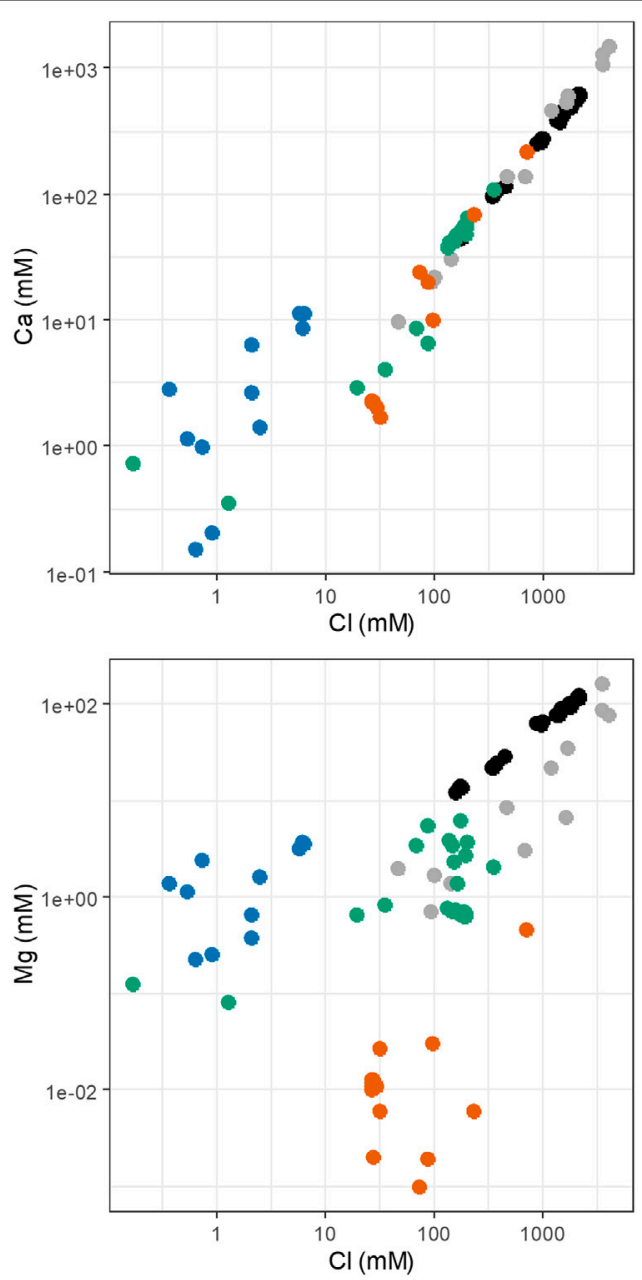

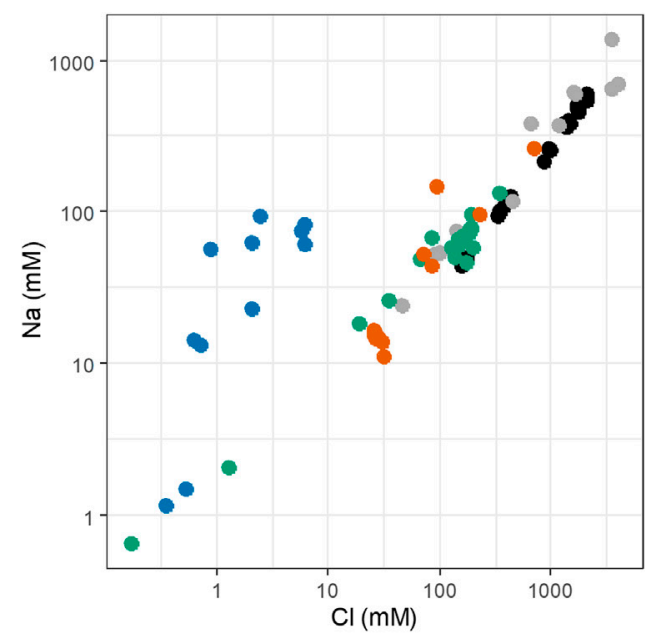

Region

- Canadian Shield

- Fennoscandian Shield

- Great Plains

- Soudan

- South African Platform

FIGURE 8 | Variation in major ion concentrations among deep biosphere research sites in different regions. Canadian Shield data were published in (Onstott et al., 2009), (Telling et al., 2018), and (Lollar et al., 2019). Fennoscandian Shield data were published in (Pedersen, 1997), (Itävaara et al., 2011), and (Wu et al., 2016). Great Plains data were published in (Osburn et al., 2014). South African Platform data were published in (Baker et al., 2003), (Moser et al., 2003), (Kieft et al., 2005), and (Lin et al., 2006).

geochemical and microbiological data. In addition to the regions discussed above, the Deep Mine Microbial Observatory (DeMMO) was chosen as an additional reference point. This site, located in South Dakota, is another recently established deep biosphere research laboratory with thoroughly characterized water and rock chemistry (Osburn et al., 2019). The DeMMO site can demonstrate how the chemistry of younger, less saline waters compares with the older crustal brines.

Overall, $\mathrm{Ca}^{2+}$ and $\mathrm{Na}^{+}$have similar correlation with overall salinity for all concentrated brines, while less saline waters from all sites seem to deviate from this line. Greater deviation is seen for the waters from DeMMO, as it does not seem to derive its salinity from mixing with a highly concentrated brine. Distinct regional differences are seen for magnesium concentrations: South African waters have quite low $\mathrm{Mg}^{2+}$ concentrations relative to overall salinity, while Soudan is enriched in $\mathrm{Mg}^{2+}$ even relative to most Canadian Shield sites. As the chemistry of these deep groundwaters is heavily influenced by local rock chemistry, even relatively biologically inert elements like these major ions may be a way to pinpoint geochemical features that provide unique environments for microbes.

\section{CONCLUSION}

The field of research into the deep biosphere is no longer so young that the mere existence of subsurface life is necessarily noteworthy. As microbial life is expected to exist in most subsurface groundwaters, the reasoning behind a focus on a specific site has become increasingly important. One must understand the features making a given site unique as well as the ways it resembles previously studied sites. Microbial life in deep subsurface groundwaters is intimately intertwined with the geology, so comprehensive studies of the chemistry, 
geology, hydrology, and microbiology of a given site are critical to fully understanding life in these energy limited environments. Furthermore, between-site comparisons shed light on the broad biogeochemical characteristics of these environments. Hydrologic connections play an important role in allowing organisms to travel from surface to site and through fracture networks (Borgonie et al., 2019). The residence time of these subsurface waters, used as a proxy for isolation from the surface, indicates the potential for evolution of a community distinct from those on the surface. Connectivity to the surface or to other deep groundwaters shapes how potential substrates flow through deep communities and may be a factor controlling microbial diversity (Hubalek et al., 2016). Indeed, water chemistry is likely a major driver of changes to subsurface ecosystems. Changes in water chemistry within a single borehole correlate with changes in the microbial communities residing therein (Kietäväinen et al., 2013). Water chemistry may also serve as a marker for differences in subsurface lithology between groundwaters (Onstott et al., 2006; Bucher and Stober, 2011). This is important, as lithology is also likely to be a vital predictor of subsurface communities. Mineralogy has been shown to control microbial community composition both on the ocean floor and in the ocean crust (Santelli et al., 2009; Smith and Roychoudhury, 2013; Toner et al., 2013; Smith et al., 2017). Additionally, the bulk of the microbial population in the deep biosphere likely resides on rock and mineral surfaces rather than in planktonic communities floating in the water (Flemming and Wuertz, 2019). These rock-hosted communities may be quite distinct from the hitherto observed aqueous communities (Momper et al., 2017). Until a more comprehensive understanding of these rock-hosted communities is reached, an understanding of how lithologies shape aqueous communities and the chemistry of the waters they live in may help bridge this gap.

\section{REFERENCES}

Ahonen, L., Kortelainen, N., Kukkonen, I. T., Pullinen, A., Toppi, T., Bomberg, M., et al. (2011). Hydrogeological Characteristics of the Outokumpu Deep Drill Hole. Spec. Pap. Geol. Surv. Finl. 2011, 151-168.

Badalamenti, J. P., Summers, Z. M., Chan, C. H., Gralnick, J. A., and Bond, D. R. (2016). Isolation and Genomic Characterization of 'Desulfuromonas Soudanensis WTL', a Metal- and Electrode-Respiring Bacterium from Anoxic Deep Subsurface Brine. Front. Microbiol. 7, 913-1011. doi:10.3389/ fmicb.2016.00913

Baker, B. J., Moser, D. P., MacGregor, B. J., Fishbain, S., Wagner, M., Fry, N. K., et al. (2003). Related Assemblages of Sulphate-Reducing Bacteria Associated with Ultradeep Gold Mines of South Africa and Deep basalt Aquifers of Washington State. Environ. Microbiol. 5, 267-277. doi:10.1046/j.1462-2920. 2003.00408.x

Bakkila, H. E. (1960a). Exploration Drill Hole Record: DDH 942. Eveleth, MN. Bakkila, H. E. (1960b). Exploration Drill Hole Record: DDH 944. Virginia, MN. Bakkila, H. E. (1960c). Exploration Drill Hole Record: DDH 951. Eveleth, MN.

Bell, E., Lamminmäki, T., Alneberg, J., Andersson, A. F., Qian, C., Xiong, W., et al. (2018). Biogeochemical Cycling by a Low-Diversity Microbial Community in Deep Groundwater. Front. Microbiol. 9, 1-17. doi:10.3389/fmicb.2018.02129

\section{DATA AVAILABILITY STATEMENT}

The water chemistry data generated for this study can be found in the EarthChem Library: https://doi.org/10.26022/IEDA/112169.

\section{AUTHOR CONTRIBUTIONS}

CJS compiled the data, prepared the figures, and wrote the manuscript with input from CMS and BT. CJS, LB, SA, EA, JG, CMS, and BT contributed to the design of the study. LB, SA, EA, and BT collected and analysed samples. All authors contributed to the article and approved the submitted version.

\section{FUNDING}

This work was supported by the National Science Foundation's Integrated Earth Systems Program Grant EAR-1813526 and by the Legislative Citizen Commission on Minnesota Resources Grant 216-G.

\section{ACKNOWLEDGMENTS}

We thank the Minnesota Department of Natural Resources for allowing us to access and sample the Soudan Underground Mine State Park. We would especially like to thank Park Manager James Essig and his staff for their time and guidance; this research would not have been possible without their help.

\section{SUPPLEMENTARY MATERIAL}

The Supplementary Material for this article can be found online at: https://www.frontiersin.org/articles/10.3389/feart.2022.803250/ full\#supplementary-material

Bonis, B. M., and Gralnick, J. A. (2015). Marinobacter Subterrani, a Genetically Tractable Neutrophilic Fe(II)-oxidizing Strain Isolated from the Soudan Iron Mine. Front. Microbiol. 6, 1-11. doi:10.3389/fmicb.2015.00719

Borgonie, G., Magnabosco, C., García-Moyano, A., Linage-Alvarez, B., Ojo, A. O., Freese, L. B., et al. (2019). New Ecosystems in the Deep Subsurface Follow the Flow of Water Driven by Geological Activity. Sci. Rep. 9, 3310-3316. doi:10. 1038/s41598-019-39699-w

Borgonie, G., García-Moyano, A., Litthauer, D., Bert, W., Bester, A., Van Heerden, E., et al. (2011). Nematoda from the Terrestrial Deep Subsurface of South Africa. Nature 474, 79-82. doi:10.1038/nature09974

Borgonie, G., Linage-Alvarez, B., Ojo, A. O., Mundle, S. O. C., Freese, L. B., Van Rooyen, C., et al. (2015). Eukaryotic Opportunists Dominate the DeepSubsurface Biosphere in South Africa. Nat. Commun. 6, 1-12. doi:10.1038/ ncomms 9952

Bottomley, D. J., Conrad Gregoire, D., and Raven, K. G. (1994). Saline Ground Waters and Brines in the Canadian Shield: Geochemical and Isotopic Evidence for a Residual Evaporite Brine Component. Geochimica et Cosmochimica Acta 58, 1483-1498. doi:10.1016/0016-7037(94)90551-7

Bottomley, D. J., Katz, A., Chan, L. H., Starinsky, A., Douglas, M., Clark, I. D., et al. (1999). The Origin and Evolution of Canadian Shield Brines: Evaporation or Freezing of Seawater? New Lithium Isotope and Geochemical Evidence from the Slave Craton. Chem. Geology 155, 295-320. doi:10.1016/s0009-2541(98)00166-1 
Bottomley, D. J., Renaud, R., Kotzer, T., and Clark, I. D. (2002). Iodine-129 Constraints on Residence Times of Deep marine Brines in the Canadian Shield. Geol. 30, 587-590. doi:10.1130/0091-7613(2002)030<0587:icorto >2.0.co;2

Bucher, K., and Stober, I. (2011). Fluids in the Upper Continental Crust. Geofluids 10, 241-254. doi:10.1111/j.1468-8123.2010.00279x

Chivian, D., Brodie, E. L., Alm, E. J., Culley, D. E., Dehal, P. S., Desantis, T. Z., et al. (2008) Environmental Genomics Reveals a Single-Species Ecosystem Deep within Earth. Science 322, 275-278. doi:10.1126/science.1155495

Cloud, P. E., Jr., Gruner, J. W., and Hagen, H. (1965). Carbonaceous Rocks of the Soudan Iron Formation (Early Precambrian). Science 148, 1713-1716. doi:10. 1126/science.148.3678.1713

Dahlberg, E. H., Peterson, D., and Frey, B. A. (1989). 1988 - 1989 Drill Core Repository Sampling Projects. Hibbing, MN.

Duane, M. J., Pigozzi, G., and Harris, C. (1997). Geochemistry of Some Deep Gold Mine Waters from the Western Portion of the Witwatersrand Basin, South Africa. J. Afr. Earth Sci. 24, 105-123. doi:10.1016/s0899-5362(97)00030-4

Edwards, R. A., Rodriguez-Brito, B., Wegley, L., Haynes, M., Breitbart, M., Peterson, D. M., et al. (2006). Using Pyrosequencing to Shed Light on Deep Mine Microbial Ecology. BMC Genomics 7, 57-13. doi:10.1186/1471-2164-7-57

Ekendahl, S., O’Neill, A. H., Thomsson, E., and Pedersen, K. (2003). Characterisation of Yeasts Isolated from Deep Igneous Rock Aquifers of the Fennoscandian Shield. Microb. Ecol. 46, 416-428. doi:10.1007/s00248-003-2008-5

Flemming, H.-C., and Wuertz, S. (2019). Bacteria and Archaea on Earth and Their Abundance in Biofilms. Nat. Rev. Microbiol. 17, 247-260. doi:10.1038/s41579019-0158-9

Franklyn, M. T., McNutt, R. H., Kamineni, D. C., Gascoyne, M., and Frape, S. K. (1991). Groundwater 87Sr/86Sr Values in the Eye-Dashwa Lakes Pluton, Canada: Evidence for Plagioclase-Water Reaction. Chem. Geology Isotope Geosci. Section 86, 111-122. doi:10.1016/0168-9622(91)90057-4

Frape, S. K., Fritz, P., and McNutt, R. H. (1984). Water-rock Interaction and Chemistry of Groundwaters from the Canadian Shield. Geochimica et Cosmochimica Acta 48, 1617-1627. doi:10.1016/0016-7037(84)90331-4

Fritz, P., and Frape, S. K. (1982). Saline Groundwaters in the Canadian Shield - A First Overview. Chem. Geology 36, 179-190. doi:10.1016/0009-2541(82) 90045-6

Giunta, T., Young, E. D., Warr, O., Kohl, I., Ash, J. L., Martini, A., et al. (2019). Methane Sources and Sinks in continental Sedimentary Systems: New Insights from Paired Clumped Isotopologues ${ }^{13} \mathrm{CH}_{3} \mathrm{D}$ and ${ }^{12} \mathrm{CH}_{2} \mathrm{D}_{2}$. Geochimica et Cosmochimica Acta 245, 327-351. doi:10.1016/j.gca.2018.10.030

Holland, G., Lollar, B. S., Li, L., Lacrampe-Couloume, G., Slater, G. F., and Ballentine, C. J. (2013). Deep Fracture Fluids Isolated in the Crust since the Precambrian Era. Nature 497, 357-360. doi:10.1038/nature12127

Hubalek, V., Wu, X., Eiler, A., Buck, M., Heim, C., Dopson, M., et al. (2016). Connectivity to the Surface Determines Diversity Patterns in Subsurface Aquifers of the Fennoscandian Shield. ISME J. 10, 2447-2458. doi:10.1038/ ismej.2016.36

Itävaara, M., Nyyssönen, M., Kapanen, A., Nousiainen, A., Ahonen, L., and Kukkonen, I. (2011). Characterization of Bacterial Diversity to a Depth of $1500 \mathrm{~m}$ in the Outokumpu Deep Borehole, Fennoscandian Shield. FEMS Microbiol. Ecol. 77, 295-309.

Jones, R. M., Goordial, J. M., and Orcutt, B. N. (2018). Low Energy Subsurface Environments as Extraterrestrial Analogs. Front. Microbiol. 9, 1605-1618. doi:10.3389/fmicb.2018.01605

Kelly, W. C., Rye, R. O., and Livnat, A. (1986). Saline Minewaters of the Keweenaw Peninsula, Northern Michigan; Their Nature, Origin, and Relation to Similar Deep Waters in Precambrian Crystalline Rocks of the Canadian Shield. Am. J. Sci. 286, 281-308. doi:10.2475/ajs.286.4.281

Kieft, T. L., McCuddy, S. M., Onstott, T. C., Davidson, M., Lin, L.-H., Mislowack, B., et al. (2005). Geochemically Generated, Energy-Rich Substrates and Indigenous Microorganisms in Deep, Ancient Groundwater. Geomicrobiology J. 22, 325-335. doi:10.1080/01490450500184876

Kietäväinen, R., Ahonen, L., Kukkonen, I. T., Hendriksson, N., Nyyssönen, M., and Itävaara, M. (2013). Characterisation and Isotopic Evolution of saline Waters of the Outokumpu Deep Drill Hole, Finland - Implications for Water Origin and Deep Terrestrial Biosphere. Appl. Geochem. 32, 37-51.

Kietäväinen, R., Ahonen, L., Kukkonen, I. T., Niedermann, S., and Wiersberg, T. (2014). Noble Gas Residence Times of saline Waters within Crystalline Bedrock, Outokumpu Deep Drill Hole, Finland. Geochim. Cosmochim. Acta 145, 159-174.
Klinger, F. (1958). Exploration Drill Hole Record: DDH 932. Eveleth, MN.

Kloppmann, W., Girard, J.-P., and Négrel, P. (2002). Exotic Stable Isotope Compositions of saline Waters and Brines from the Crystalline Basement. Chem. Geology 184, 49-70. doi:10.1016/s0009-2541(01)00352-7

Li, L., Wing, B. A., Bui, T. H., McDermott, J. M., Slater, G. F., Wei, S., et al. (2016). Sulfur Mass-independent Fractionation in Subsurface Fracture Waters Indicates a Long-Standing Sulfur Cycle in Precambrian Rocks. Nat. Commun. 7, 13252. doi:10.1038/ncomms13252

Lin, L.-H., Wang, P.-L., Rumble, D., Lippmann-pipke, J., Boice, E., Pratt, L. M., et al. (2006). Long-Term Sustainability of a High-Energy, Low-Diversity Crustal Biome. Science 314, 479-482. doi:10.1126/science.1127376

Lin, L. H., Hall, J., Lippmann-Pipke, J., Ward, J. A., Lollar, B. S., DeFlaun, M., et al. (2005). Radiolytic H2 in continental Crust: Nuclear Power for Deep Subsurface Microbial Communities. Geochemistry, Geophys. Geosystems 6, 1-13. doi:10. 1029/2004gc000907

Lollar, B. S., Lacrampe-Couloume, G., Voglesonger, K., Onstott, T. C., Pratt, L. M., and Slater, G. F. (2008). Isotopic Signatures of CH4 and Higher Hydrocarbon Gases from Precambrian Shield Sites: A Model for Abiogenic Polymerization of Hydrocarbons. Geochimica et Cosmochimica Acta 72, 4778-4795. doi:10.1016/j. gca.2008.07.004

Lollar, G. S., Warr, O., Telling, J., Osburn, M. R., and Lollar, B. S. (2019). 'Follow the Water': Hydrogeochemical Constraints on Microbial Investigations $2.4 \mathrm{Km}$ below Surface at the Kidd Creek Deep Fluid and Deep Life Observatory. Geomicrobiology J. 36, 859-872. doi:10.1080/01490451.2019.1641770

Lopez-Fernandez, M., Simone, D., Wu, X., Soler, L., Nilsson, E., Holmfeldt, K., et al. (2018b). Metatranscriptomes Reveal that All Three Domains of Life Are Active but Are Dominated by Bacteria in the Fennoscandian Crystalline Granitic Continental Deep Biosphere. MBio 9, 1-15. doi:10.1128/mBio.01792-18

Lopez-Fernandez, M., Åström, M., Bertilsson, S., and Dopson, M. (2018a). Depth and Dissolved Organic Carbon Shape Microbial Communities in Surface Influenced but Not Ancient saline Terrestrial Aquifers. Front. Microbiol. 9, 1-16. doi:10.3389/fmicb.2018.02880

Lovley, D. R., and Chapelle, F. H. (1995). Deep Subsurface Microbial Processes. Rev. Geophys. 33, 365-381. doi:10.1029/95rg01305

Magnabosco, C., Timmers, P. H. A., Lau, M. C. Y., Borgonie, G., Linage-Alvarez, B., Kuloyo, O., et al. (2018). Fluctuations in Populations of Subsurface Methane Oxidizers in Coordination with Changes in Electron Acceptor Availability. FEMS Microbiol. Ecol. 94, 1-10. doi:10.1093/femsec/fiy089

McNutt, R. H., Frape, S. K., Fritz, P., Jones, M. G., and MacDonald, I. M. (1990). The Values of Canadian Shield Brines and Fracture Minerals with Applications to Groundwater Mixing, Fracture History, and Geochronology. Geochimica et Cosmochimica Acta 54, 205-215. doi:10.1016/0016-7037(90)90208-3

Momper, L., Kiel Reese, B., Zinke, L., Wanger, G., Osburn, M. R., Moser, D., et al. (2017). Major Phylum-Level Differences between Porefluid and Host Rock Bacterial Communities in the Terrestrial Deep Subsurface. Environ. Microbiol. Rep. 9, 501-511. doi:10.1111/1758-2229.12563

Moser, D. P., Gihring, T. M., Brockman, F. J., Fredrickson, J. K., Balkwill, D. L., Dollhopf, M. E., et al. (2005). Desulfotomaculum and Methanobacterium Spp. Dominate a 4- to 5-Kilometer-Deep Fault. Appl. Environ. Microbiol. 71, 8773-8783. doi:10.1128/aem.71.12.8773-8783.2005

Moser, D. P., Onstott, T. C., Fredrickson, J. K., Brockman, F. J., Balkwill, D. L., Drake, G. R., et al. (2003). Temporal Shifts in the Geochemistry and Microbial Community Structure of an Ultradeep Mine Borehole Following Isolation. Geomicrobiology J. 20, 517-548. doi:10.1080/713851170

Nielsen, M. E., Fisk, M. R., Istok, J. D., and Pedersen, K. (2006). Microbial Nitrate Respiration of Lactate at In Situ Conditions in Ground Water from a Granitic Aquifer Situated 450 M Underground. Geobiology 4, 43-52. doi:10.1111/j.14724669.2006.00068.x

Nordstrom, D. K., Ball, J. W., Donahoe, R. J., and Whittemore, D. (1989). Groundwater Chemistry and Water-Rock Interactions at Stripa. Geochimica et Cosmochimica Acta 53, 1727-1740. doi:10.1016/0016-7037(89)90294-9

Nurmi, P. A., Kukkonen, I. T., and Lahermo, P. W. (1988). Geochemistry and Origin of saline Groundwaters in the Fennoscandian Shield. Appl. Geochem. 3, 185-203. doi:10.1016/0883-2927(88)90007-8

O'Neil, J., and Carlson, R. W. (2017). Building Archean Cratons from Hadean Mafic Crust. Science 355, 1199-1202.

Onstott, T. C., Lin, L.-H., Davidson, M., Mislowack, B., Borcsik, M., Hall, J., et al. (2006). The Origin and Age of Biogeochemical Trends in Deep Fracture Water 
of the Witwatersrand basin, south africa. Geomicrobiology J. 23, 369-414. doi:10.1080/01490450600875688

Onstott, T. C., McGown, D. J., Bakermans, C., Ruskeeniemi, T., Ahonen, L., Telling, J., et al. (2009). Microbial Communities in Subpermafrost saline Fracture Water at the Lupin Au Mine, Nunavut, Canada. Microb. Ecol. 58, 786-807. doi:10.1007/s00248-009-9553-5

Osburn, M., Kruger, B., Masterson, A., Casar, C., and Amend, J. (2019). Eatablishment of the Deep Mine Microbial Observatory (DeMMO), South Dakota, USA, a Geologically Stable portal into the Deep Subsurface. Front. Earth Sci. 7, 1-17. doi:10.3389/feart.2019.00196

Osburn, M. R., LaRowe, D. E., Momper, L. M., and Amend, J. P. (2014). Chemolithotrophy in the continental Deep Subsurface: Sanford Underground Research Facility (SURF), USA. Front. Microbiol. 5, 610-614. doi:10.3389/fmicb.2014.00610

Pedersen, K., Arlinger, J., Ekendahl, S., and Hallbeck, L. (1996). 16S rRNA Gene Diversity of Attached and Unattached Bacteria in Boreholes along the Access Tunnel to the Ã "sp̃̃ Hard Rock Laboratory, Sweden. FEMS Microbiol. Ecol. 19, 249-262. doi:10.1111/j.1574-6941.1996.tb00217.x

Pedersen, K. (1997). Microbial Life in Deep Granitic Rock. FEMS Microbiol. Rev. 20, 399-414. doi:10.1111/j.1574-6976.1997.tb00325.x

Peterson, D. M. (2019). Geologic Map of the 27th Level of the Soudan Mine. St. Louis County, Minnesota.

Peterson, D. M. (2007). Imagining Scientific Realities Deep Underground: Utilizing Knowledge and 3-D Geological Modeling. Duluth, MN: Fundamental Tenets of the University of Minnesota's Proposed Institute for Underground Science and Soudan DUSEL.

Peterson, D. M., and Patelke, R. L. (2003). National Underground Science and Engineering Laboratory (NUSEL): Geological Site Investigation for the Soudan Mine, Northeastern Minnesota. Minnesota Duluth, MN.

Purkamo, L., Bomberg, M., Kietäväinen, R., Salavirta, H., Nyyssönen, M., Nuppunen-Puputti, M., et al. (2016). Microbial Co-occurrence Patterns in Deep Precambrian Bedrock Fracture Fluids. Biogeosciences 13, 3091-3108. doi:10.5194/bg-13-3091-2016

Santelli, C. M., Edgcomb, V. P., Bach, W., and Edwards, K. J. (2009). The Diversity and Abundance of Bacteria Inhabiting Seafloor Lavas Positively Correlate with Rock Alteration. Environ. Microbiol. 11, 86-98. doi:10.1111/j.1462-2920.2008.01743.x

Sheik, C. S., Badalamenti, J. P., Telling, J., Hsu, D., Alexander, S. C., Bond, D. R., et al. (2021). Novel Microbial Groups Drive Productivity in an Archean Iron Formation. Front. Microbiol. 12, 616. doi:10.3389/fmicb.2021.627595

Sherwood Lollar, B., Frape, S. K., Fritz, P., Macko, S. A., Welhan, J. A., Blomqvist, R., et al. (1993). Evidence for Bacterially Generated Hydrocarbon Gas in Canadian Shield and Fennoscandian Shield Rocks. Geochimica et Cosmochimica Acta 57, 5073-5085. doi:10.1016/0016-7037(93)90609-z

Sherwood Lollar, B., Lacrampe-Couloume, G., Slater, G. F., Ward, J., Moser, D. P., Gihring, T. M., et al. (2006). Unravelling Abiogenic and Biogenic Sources of Methane in the Earth's Deep Subsurface. Chem. Geology 226, 328-339. doi:10. 1016/j.chemgeo.2005.09.027

Sherwood Lollar, B., Westgate, T. D., Ward, J. A., Slater, G. F., and LacrampeCouloume, G. (2002). Abiogenic Formation of Alkanes in the Earth's Crust as a Minor Source for Global Hydrocarbon Reservoirs. Nature 416, 522-524. doi:10. 1038/416522a

Simkus, D. N., Slater, G. F., Lollar, B. S., Wilkie, K., Kieft, T. L., Magnabosco, C., et al. (2016). Variations in Microbial Carbon Sources and Cycling in the Deep continental Subsurface. Geochimica et Cosmochimica Acta 173, 264-283. doi:10.1016/j.gca.2015.10.003

Smith, A. R., Fisk, M. R., Thurber, A. R., Flores, G. E., Mason, O. U., Popa, R., et al. (2017). Deep Crustal Communities of the Juan de Fuca Ridge Are Governed by
Mineralogy. Geomicrobiology J. 34, 147-156. doi:10.1080/01490451.2016. 1155001

Smith, M., and Roychoudhury, A. N. (2013). Mobilisation of Iron from Rocks in a Fractured Aquifer: Lithological and Geochemical Controls. Appl. Geochem. 31, 171-186. doi:10.1016/j.apgeochem.2013.01.002

Starinsky, A., and Katz, A. (2003). The Formation of Natural Cryogenic Brines. Geochimica et Cosmochimica Acta 67, 1475-1484. doi:10.1016/s0016-7037(02) 01295-4

Stevens, T. O., and Mckinley, J. P. (1995). Lithoautotrophic Microbial Ecosystems in Deep Basalt Aquifers. Science 270, 450-455. doi:10.1126/science.270. 5235.450

Stotler, R. L., Frape, S. K., Ruskeeniemi, T., Ahonen, L., Onstott, T. C., and Hobbs, M. Y. (2009). Hydrogeochemistry of Groundwaters in and below the Base of Thick Permafrost at Lupin, Nunavut, Canada. J. Hydrol. 373, 80-95. doi:10. 1016/j.jhydrol.2009.04.013

Stotler, R. L., Frape, S. K., Ruskeeniemi, T., Pitkänen, P., and Blowes, D. W. (2012). The Interglacial-Glacial Cycle and Geochemical Evolution of Canadian and Fennoscandian Shield Groundwaters. Geochimica et Cosmochimica Acta 76, 45-67. doi:10.1016/j.gca.2011.10.006

Szewzyk, U., Szewzyk, R., and Stenström, T. A. (1994). Thermophilic, Anaerobic Bacteria Isolated from a Deep Borehole in Granite in Sweden. Proc. Natl. Acad. Sci. U. S. A. 91, 1810-1813. doi:10.1073/pnas.91.5.1810

Telling, J., Voglesonger, K., Sutcliffe, C. N., Lacrampe-Couloume, G., Edwards, E., and Sherwood Lollar, B. (2018). Bioenergetic Constraints on Microbial Hydrogen Utilization in Precambrian Deep Crustal Fracture Fluids. Geomicrobiology J. 35, 108-119. doi:10.1080/01490451.2017. 1333176

Toner, B. M., Lesniewski, R. A., Marlow, J. J., Briscoe, L. J., Santelli, C. M., Bach, W., et al. (2013). Mineralogy Drives Bacterial Biogeography of Hydrothermally Inactive Seafloor Sulfide Deposits. Geomicrobiology J. 30, 313-326. doi:10.1080/ 01490451.2012 .688925

Wu, X., Holmfeldt, K., Hubalek, V., Lundin, D., Åström, M., Bertilsson, S., et al. (2016). Microbial Metagenomes from Three Aquifers in the Fennoscandian Shield Terrestrial Deep Biosphere Reveal Metabolic Partitioning Among Populations. ISME J. 10, 1192-1203. doi:10.1038/ ismej.2015.185

Thompson, A. (2015) A Hydrothermal Model for Metasomatism of Neoarchean Algoma- Type Banded Iron Formation to Massive Hematite Ore at the Soudan Mine, NE Minnesota. University of Minnesota, Duluth.

Conflict of Interest: The authors declare that the research was conducted in the absence of any commercial or financial relationships that could be construed as a potential conflict of interest.

Publisher's Note: All claims expressed in this article are solely those of the authors and do not necessarily represent those of their affiliated organizations, or those of the publisher, the editors and the reviewers. Any product that may be evaluated in this article, or claim that may be made by its manufacturer, is not guaranteed or endorsed by the publisher.

Copyright $\odot 2022$ Schuler, Briscoe, Alexander, Alexander, Gralnick, Santelli and Toner. This is an open-access article distributed under the terms of the Creative Commons Attribution License (CC BY). The use, distribution or reproduction in other forums is permitted, provided the original author(s) and the copyright owner(s) are credited and that the original publication in this journal is cited, in accordance with accepted academic practice. No use, distribution or reproduction is permitted which does not comply with these terms. 